\title{
Are Groundwater Monitoring Networks Economical? Cost-Benefit Analysis on the Long-Term Groundwater Supply Project of South Korea
}

\author{
Sun G. Kim ${ }^{1}\left(\mathbb{D}\right.$ and Gyoo-Bum Kim ${ }^{2, *}$ \\ 1 Department of International Economics and Business, Daejeon University, Daejeon 300-716, Korea; \\ sunkim@dju.ac.kr \\ 2 Department of Construction Safety and Disaster Prevention, Daejeon University, Daejeon 300-716, Korea \\ * Correspondence: geowater@dju.ac.kr
}

Received: 10 February 2019; Accepted: 2 April 2019; Published: 11 April 2019

check for updates

\begin{abstract}
Analyses of the relative economic efficiencies of surface-water and groundwater are important for policy-makers in many water-stressed countries. Groundwater is becoming an increasingly attractive and viable option as a supplementary water source, but its economic background must be understood before implementation. Employing the basic frameworks of the British and US Geological Surveys, we examined the economic viability of groundwater monitoring networks in South Korea, based on an analytic hierarchy process (AHP), pairwise comparison, and cost-benefit analysis. The total cost including installation, maintenance and servicing over the next 50 years is estimated to be US $\$ 0.79$ billion, while the benefits are valued at US\$ 2.31 billion. The monitoring network should provide benefits worth $292 \%$ of the costs, with the monitoring project thus clearly being economically viable. A sensitivity analysis indicates that the monitoring project is still economical, even if the network installation schedule is delayed slightly. As this study combines both economic and scientific perspectives, it might provide a concrete economic background for implementing groundwater utilization projects elsewhere.
\end{abstract}

Keywords: groundwater; monitoring network; cost-benefit analysis; AHP; pairwise comparison

\section{Introduction}

Water is becoming one of the most pressing societal and geopolitical issues for sustainable development in some Asian regions. It is projected that more than $40 \%$ of the world's population will be living in seriously water-stressed areas by 2035, with the availability of ecosystems to provide fresh water becoming increasingly compromised [1]. United Nations University [1] warned that only $60 \%$ of water demand will be met by existing resources in the South and Southeast Asian regions by 2030. The World Bank [2] reported that unless government action is taken soon, water scarcity could cost some regions up to $6 \%$ of their GDP, spur migration and spark conflict, especially for East Asia and Central Africa.

The effectiveness of water management varies among countries, and rapid development of groundwater resources would be needed in most countries for them to become a viable water source. Groundwater is part of an overall hydrologic system including surface water, and is important in supplying water for irrigation, manufacturing and for other uses. While underground sources provide $80-90 \%$ of available water in the US and Europe, they supply only $11 \%$ of the total in Korea [1].

With increasing storage and distribution costs of surface-water, groundwater is becoming an increasingly attractive substitute for surface water [3], but the establishment of a national groundwater monitoring system to gauge the level, temperature, $\mathrm{pH}$, and quality of groundwater is expensive. 
Since continuous monitoring of any changes in groundwater is a basic role of government, to ensure improvement in groundwater management for water supply as Korea shifts from a largely surface-water based economy to an increasingly groundwater based one, its economic feasibility has become more important. Many approaches based on economic perspectives have been applied to ground and surface water in the US, Spain, UK and other countries [4-7]. The control of underground aquifers, the intensive use of groundwater resources, and the potential changes in both groundwater quality and quantity command the attention of both scientific specialists and policy makers, with economic issues associated with establishing facilities for groundwater supply being important. The economic assessment of groundwater supplies therefore requires a multidisciplinary approach covering costs, water supply policy, water quantity and quality, and applications.

The economic analysis of groundwater based on data provided by monitoring networks should consider not only the efficient use and management of resources, but also the consequential improvements in the ability to cope with related adverse issues such as droughts, and their accompanying risks to the environment, property and life.

South Korea currently has relatively few groundwater monitoring networks compared with major European countries, although there is a national plan to increase monitoring over the next 30 years [8]. However, a systematic analysis of the long-term value of such networks has not yet been undertaken in South Korea, with no economic research into the value of national projects related to groundwater supply. One of the main objectives of this study is to investigate the economic feasibility of groundwater monitoring networks which require the lion's share of the national budget in completing the long-term groundwater supply project; that is, the economic value of the information acquired from the networks is analysed with respect to its cost-benefit relationship, and the adequacy of the evaluation is reassessed through a sensitivity analysis.

\subsection{Groundwater Monitoring Networks: Current Facts and Plans}

South Korea has been constructing monitoring wells since 1995 to observe the level and quality of groundwater. All six types of groundwater monitoring networks are currently operated with their own objectives: the National Groundwater Monitoring Network (NGMN); the Subsidiary Groundwater Monitoring Network (SGMN); the Groundwater Quality Monitoring Network (GQM including GQMN (Basic Groundwater Quality Monitoring Network) and GPMN (Groundwater Pollution Monitoring Network)); the Local Groundwater Quality Monitoring Network (LQMN); the Groundwater Monitoring Network in Farming Areas (GMFA); and the Seawater Intrusion Monitoring Network (SIMN) [8-10].

The NGMN, GQMN, and GPMN are managed by the central government, and the others are operated by local governments or agencies. They are installed in representative sites according to field characteristics such as land type, topography, hydrogeological measures, background water quality, pollution source, and underground water disturbances. These monitoring networks essentially measure either groundwater levels or groundwater quality. The Groundwater Management Plan has each type of monitoring network scheduled to be installed at the same densities as developed countries by the year 2030 [8] (Figure 1). Therefore, the plan targets 0.10 wells per $\mathrm{km}^{2}$ for SGMN, 0.33 wells per $\mathrm{km}^{2}$ for GPMN, 0.01 wells per $\mathrm{km}^{2}$ for GMFA, and 0.034 wells per $\mathrm{km}^{2}$ for LQMN. 


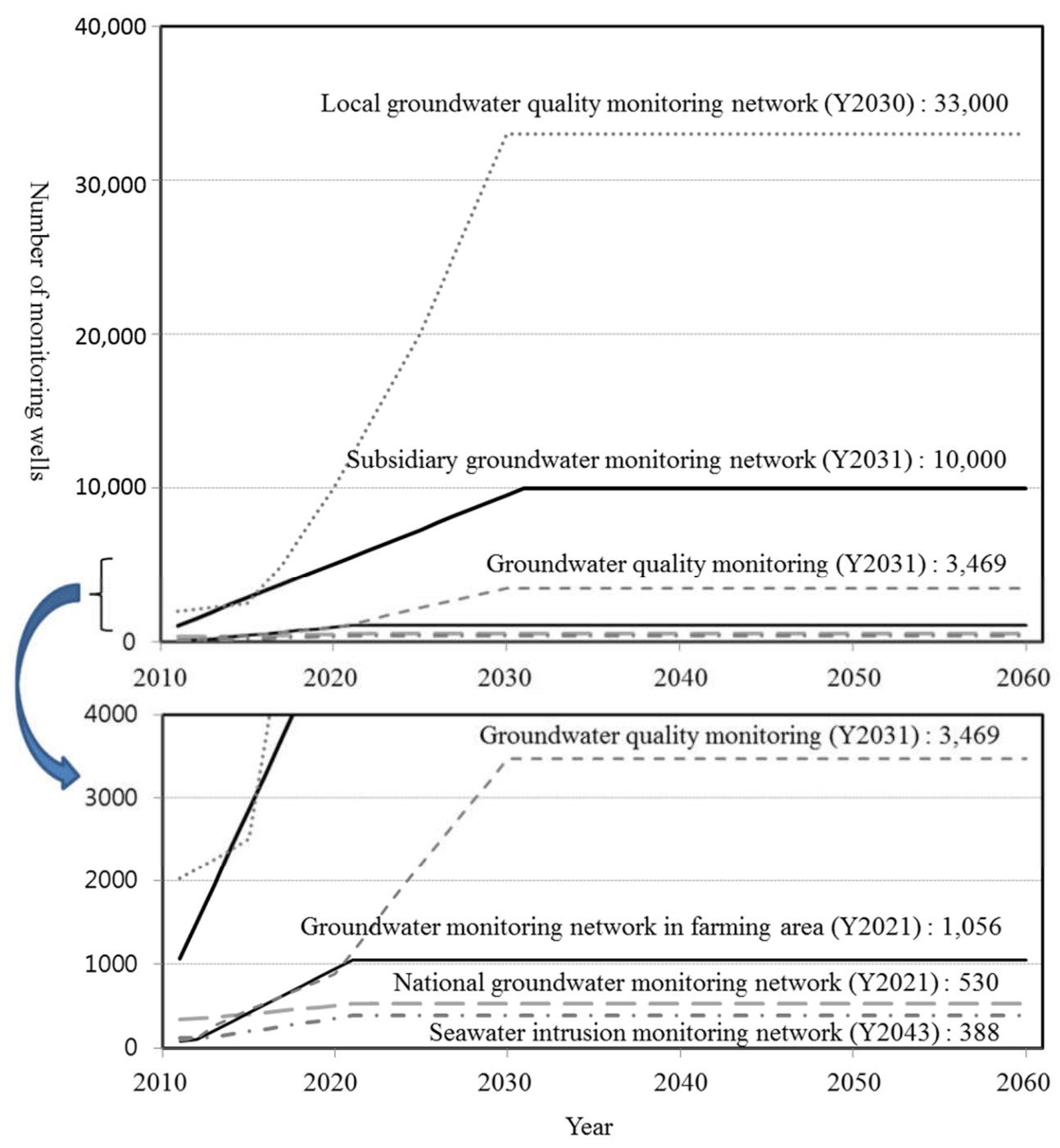

Figure 1. Current groundwater monitoring networks and future plans in South Korea. Source: Ministry of Land, Infrastructure and Transport [8]. Note: (1) The sum of the GQMN and the GPMN is displayed as the GQM. (2) This figure is drawn by the authors.

As a primary network, the purpose of the NGMN was to measure long-term trends in groundwater levels [11]. Its installation began in 1995 and the government plans to increase the number of wells to 530 by 2021 [8]. The GQMN, another primary network, was established to measure background groundwater quality in non-polluted areas. The established background level can be used as a target level when improving polluted groundwater. The Ministry of Environment plans to expand this to 435 sites by 2020 and to 1305 sites by 2030. Electrical conductivity, $\mathrm{pH}$, and temperature are measured automatically, and water samples and analysis are taken twice a year. The GPMN, as a secondary monitoring system, was designed to detect and monitor groundwater contamination in areas likely to be contaminated, such as industrial complexes, closed mines, sanitary landfills, and golf courses. The Ministry of Environment plans to install 2164 of these monitoring wells by 2030. The GQM includes both the GQMN and the GPMN.

The number of these networks was not enough to detect local drawdowns of groundwater levels or contamination due to the complex geology in South Korea and therefore other networks (SGMN, LQMN, GMFA, and SIMN) were additionally proposed [11]. The SGMN was established to measure groundwater levels in the areas not covered by the NGMN, which was proposed to have 10,000 sites by 2031. The LQMN, which is managed by local governments, will be installed at 33,000 sites by 2030; its aim is to measure local groundwater quality. The GMFA will contain 1056 sites by 2021, and 
automatic measurement systems will be introduced to observe groundwater conditions related to crop production in rural cultivation areas. The SIMN measures seawater intrusions in coastal or island areas, and will contain 388 sites by 2043 [8].

\subsection{Literature Review}

Whereas the installation and management costs of the networks are fairly straightforward to assess, the benefits of the groundwater monitoring network are difficult to quantify because they include non-use value as well as use value and there is no complete assessment procedure for groundwater monitoring benefits. This means that an indirect approach, such as the analytic hierarchy process with a pairwise comparison, for the estimation of its benefits, can be a more effective tool than a direct estimation. In this study, geological information is used as a relative factor to compare with groundwater information acquired from the monitoring networks because the economic effects of geological information are well defined in many countries.

Studies by the British Geological Survey (BGS) showed two evaluation approaches for measuring the benefits of geological information: an anecdotal approach and a formal assessment as summarized below (Table 1).

Table 1. Previous studies measuring the value of geological information [12,13].

\begin{tabular}{|c|c|c|c|}
\hline Main Method & Study (Institution) & Case & Empirical Result \\
\hline \multirow{6}{*}{$\begin{array}{l}\text { Anecdotal and Formal } \\
\text { Cost-benefit } \\
\text { (Cost-effectiveness) } \\
\text { Approach }\end{array}$} & $\begin{array}{l}\text { Ellison and Calow (1996) } \\
\text { (BGS) [12] }\end{array}$ & $\begin{array}{l}\text { Evaluates the impacts of information } \\
\text { gained through geological mapping } \\
\text { projects in the UK. }\end{array}$ & $\begin{array}{l}\text { The annual national baseline value of } \\
\text { mapping of the UK is } £ 18.9 \text { million. } \\
(B / C=5.906)\end{array}$ \\
\hline & $\begin{array}{l}\text { Bernknopf et al. (1996a) } \\
\text { (USGS) [14] }\end{array}$ & $\begin{array}{l}\text { Details the rigorous development of an } \\
\text { economic model for valuing geologic } \\
\text { map information. }\end{array}$ & $\begin{array}{l}\text { The expected net benefit for the } \\
\text { 1:100,000-scale Loudoun County } \\
\text { geologic map ranges from } \$ 1.28 \text { million } \\
\text { to } \$ 3.50 \text { million. }\end{array}$ \\
\hline & $\begin{array}{l}\text { Bernknopf et al. } \\
\text { (1996b) [15] }\end{array}$ & $\begin{array}{l}\text { Estimates the economic value of } \\
\text { applying geologic map information to } \\
\text { siting a waste disposal facility in } \\
\text { Loudoun County. }\end{array}$ & $\begin{array}{l}\text { The total benefit of the improved } \\
\text { geologic map is approximately } \$ 1.5 \\
\text { million. The expected net benefit from } \\
\text { use of the } 1: 100,000 \text { scale map is } \\
\$ 0.34 \text { million. }\end{array}$ \\
\hline & $\begin{array}{l}\text { Reedman et al. (2002) } \\
\text { (BGS) [13] }\end{array}$ & $\begin{array}{l}\text { Contains an evaluation and } \\
\text { quantification of the net benefits of } \\
\text { different levels of detail and } \\
\text { improvements in interpretive models } \\
\text { contained on geologic maps. }\end{array}$ & $\begin{array}{l}\text { Various results by Bolivia, Indonesia, } \\
\text { Peru, Zimbabwe, and Nigeria. }\end{array}$ \\
\hline & $\begin{array}{l}\text { Halsing et al. (2004) } \\
\text { (USGS) [16] }\end{array}$ & $\begin{array}{l}\text { Assesses the costs and benefits of the } \\
\text { national map and to estimate its net } \\
\text { present benefit to society. }\end{array}$ & $\begin{array}{l}\text { The national map has a net present } \\
\text { value of benefits of } \$ 2.05 \text { billion with a } \\
\text { standard deviation of } \$ 490 \text { million over } \\
30 \text { years. }\end{array}$ \\
\hline & Kim et al. (2006) [17] & $\begin{array}{l}\text { Applies the BGS model (1996) to } \\
\text { estimate costs and benefits of the } \\
\text { Korean geologic mapping program. }\end{array}$ & $\begin{array}{l}\text { The total benefits ranges from } 973 \\
\text { billion Won to } 1330 \text { billion Won. The } \\
\text { costs were } 82 \text { billion Won for } 40 \text { years. }\end{array}$ \\
\hline \multirow[t]{2}{*}{$\begin{array}{l}\text { Analytical Hierarchy } \\
\text { Process (Expert-based) }\end{array}$} & $\begin{array}{l}\text { Booz Allen Hamilton } \\
(2005)[18]\end{array}$ & $\begin{array}{l}\text { Measures the value of geospatial } \\
\text { interoperability standards in accessing } \\
\text { NASA's scientific information. }\end{array}$ & $\begin{array}{l}\text { Opening geospatial standards had a } \\
\text { risk-adjusted ROI of } 119.0 \% \text { which can } \\
\text { be interpreted as for every } \$ 1 \text { spent, } \\
\$ 1.10 \text { is saved. }\end{array}$ \\
\hline & $\begin{array}{l}\text { Tsangaratos and } \\
\text { Koumantakis (2013) [19] }\end{array}$ & $\begin{array}{l}\text { Illustrates the value of geological data } \\
\text { and information used to produce } \\
\text { landslide susceptibility maps in Greece. }\end{array}$ & $\begin{array}{l}\text { Calculates weight of coefficient of each } \\
\text { factor representing the estimation of } \\
\text { landslide susceptibility. }\end{array}$ \\
\hline \multirow{3}{*}{ Willingness-To-Pay } & $\begin{array}{l}\text { Bhagwat and Berg (1991) } \\
\text { (Illinois State Geological } \\
\text { Survey) [20] }\end{array}$ & $\begin{array}{l}\text { Estimate the benefits and costs of } \\
\text { geologic mapping conducted in } 1980 \text { in } \\
\text { Illinois from interviewing with } 36 \\
\text { individuals. }\end{array}$ & $\begin{array}{l}\text { According to the most conservative } \\
\text { projection, } \mathrm{B} / \mathrm{C} \text { ratio is } 0.5 \text { to } 1.1 \text {. }\end{array}$ \\
\hline & $\begin{array}{l}\text { US Environmental } \\
\text { Protection Agency } \\
(1995)[21]\end{array}$ & $\begin{array}{l}\text { Shows an empirical technique } \\
\text { estimating changes in economic value } \\
\text { associated with changes in } \\
\text { groundwater services. }\end{array}$ & n.a. \\
\hline & $\begin{array}{l}\text { Bhagwat and Ipe (2000) } \\
\text { (Illinois State Geological } \\
\text { Survey) [22] }\end{array}$ & $\begin{array}{l}\text { Estimates the value of the geological } \\
\text { quadrangle maps (1:24,000-scale) } \\
\text { in Kentucky. }\end{array}$ & $\begin{array}{l}\text { The average willingness to pay (WTP) } \\
\text { was reported to be } \$ 342 \text { per map. } \\
\text { The value of the map was at least } 25 \text { to } \\
38 \text { times higher than the cost of the } \\
\text { mapping program. }\end{array}$ \\
\hline
\end{tabular}


Table 1. Cont.

\begin{tabular}{|c|c|c|c|}
\hline Main Method & Study (Institution) & Case & Empirical Result \\
\hline \multirow[t]{2}{*}{$\begin{array}{l}\text { Expected Utility } \\
\text { Theorem }\end{array}$} & Bouma et al. (2009) [23] & $\begin{array}{l}\text { Analyses the added value of an } \\
\text { extended satellite monitoring system } \\
\text { for the management of eutrophication, } \\
\text { potentially harmful algal blooms and } \\
\text { suspended sediment and turbidity in } \\
\text { the North Sea. }\end{array}$ & $\begin{array}{l}\text { The value of information is estimated to } \\
\text { be } € 74,000 \text { per week and the costs of the } \\
\text { new system are only } € 50,000 \text { per week. }\end{array}$ \\
\hline & $\begin{array}{l}\text { Castelein et al. } \\
\text { (2010) [24] }\end{array}$ & $\begin{array}{l}\text { Defines the geo-information sector and } \\
\text { estimate its economic value in terms of } \\
\text { turnover, employment, activities and } \\
\text { the market in Netherlands. }\end{array}$ & $\begin{array}{l}\text { The total economic value of the Dutch } \\
\text { geo-information sector was estimated at } \\
€ 1.4 \text { billion which takes a share of } 0.23 \% \\
\text { in the Dutch economy. }\end{array}$ \\
\hline
\end{tabular}

The anecdotal approach has been employed by the BGS to evaluate the impacts of new geological information. This approach was based on the compilation of national, baseline information on policy, guidance, best practice, and government research recommending the use of the information in various sectors such as minerals, waste management, environmental assessment, regional planning, water management, construction industry, education and research, tourism and recreation, agriculture, and forestry $[12,16]$.

As a formal approach, cost-benefit analysis is a simple method comparing the estimated costs and benefits of two or more alternatives. Both the BGS and the United States Geological Survey (USGS), in employing a cost-benefit analysis in their models, defined that the net benefits of each option can be represented as the "expected loss avoided" that arises from using the geological information, minus the costs of producing and disseminating the information $[13,14,16,19]$. The benefit assessment can be analyzed by comparing the economic impacts of decisions based on the already existing information. In the case of geological information, the potential value may come from: (a) direct savings in terms of avoided costs from contaminations or erosion; (b) reduced potential for liability; (c) lower costs for groundwater protection; (d) safer infrastructure; and (e) improved mineral exploration efficiency [19].

Additionally, an analytical hierarchy process (AHP) with pairwise comparison, through the interviewing of some researchers, senior-level government staff and private individuals, has been widely used to measure the value of geological and geospatial data [18,23].

Martinez-Paz et al. [25] also estimates the environmental and resource costs of groundwater by means of the Contingent Valuation Method and the Production Function Approach in the case of the Gavilán Aquifer. Face-to-face interviews were carried out to calculate use and non-use values, including open-ended questions about the WTP for protecting and preserving an aquifer located in Spain.

\section{Research Methods}

\subsection{Research Process}

Among the above four major methods of measuring the value of geological information, we chose to employ a formal cost-benefit analysis and AHP, since water supply projects have been managed not by private market but by public authorities as a public good in South Korea. The AHP is therefore an appropriate method in estimating both direct and indirect benefits of public services such as the water supply. The economic evaluation of groundwater monitoring networks is conducted by the following procedures in this study (Figure 2). First, the costs of each type of groundwater monitoring network, including the costs of construction, maintenance, replacement and water quality tests, are calculated with the existing data recorded by the management agencies or the government (see Appendix A). In the next step, the AHP method with a pairwise comparison, which is between surface water, groundwater, and geologic information, is used to estimate the relative value of the groundwater networks. In this step, the benefits of geologic information are estimated by applying the BGS model. In step 3, we examine the economic validity of the groundwater monitoring networks by comparing their benefits and costs. To ensure the validity of the economic analysis in step 4, as the sensitivity 
analysis, we reiterate the same analytic procedures and check how the cost-benefit (BC) ratio changes as the number of installed wells changes.

(1) STEP 1

Calculating cost of monitoring networks

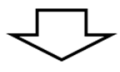

(2) STEP 2

(List of cost items for each networks)

\begin{tabular}{c|c|c|c|c|c|c}
\hline Cost items & NGMN & SGMN & GMFA & SIMN & GQM & LQMN \\
\hline Construction & 0 & 0 & 0 & 0 & 0 & 0 \\
\hline Maintenance & 0 & 0 & 0 & 0 & 0 & 0 \\
\hline Replacement & 0 & 0 & 0 & 0 & 0 & 0 \\
\hline $\begin{array}{c}\text { Water quality } \\
\text { test* }\end{array}$ & - & - & - & - & 0 & 0 \\
\hline
\end{tabular}

Calculating benefit of monitoring networks by the AHP and a pairwise comparison<smiles>C1CC2CCC12</smiles>

(3) STEP 3

Benefit and cost comparison analysis : $\mathrm{BC}$ ratio analysis for the whole monitoring networks<smiles>C1CC2CCC12</smiles>

(4) STEP 4

Sensitivity test considering a present construction trend of monitoring networks

Figure 2. Research procedure of cost-benefit analysis for groundwater monitoring networks.

\subsection{Cost-Benefit Analysis}

Since a water-related system does not aim to generate profits but has the social goal of providing a public service, the cost-benefit ratio method is more appropriate for groundwater monitoring network evaluation than other methods, as shown in some studies of the BGS and the USGS. In the cost-benefit ratio method, the ratio is calculated using the following formula [26]:

$$
\frac{B}{C}=\sum_{t=1}^{n} \frac{B_{t}}{(1+r)^{t}} / \sum_{t=1}^{n} \frac{C_{t}}{(1+r)^{t}}
$$

where $B$ is present value of benefits, $C$ is present value of costs, $r$ is discount rate, and $t$ is time. The ratio indicates how great the benefits will be per unit of costs for the project, which makes it useful in deciding whether the project should be undertaken under the condition of budget constraints or not.

This analysis is conducted under some limited assumptions according to the governmental institute's guidelines [27]. The first assumption regards the planning horizon. This study sets the time frame for the scope of this project as a period of 50 years from the construction of the monitoring wells; therefore, the period of 2011-2060 is considered here as the period generating benefits. The next condition concerns the social discount rate of the costs and benefits. Discount rates have usually been set at between $5.0 \%$ and $6.5 \%$ in South Korea. The Korea Development Institute (KDI) has usually argued for a relatively low interest rate for water resource projects that could bring long-term costs and benefits. Therefore, two discount rates of $5.0 \%$ for the initial 30 years and $6.5 \%$ for the next 20 years are used in this research model on the grounds of the KDI's guidelines which has to be applied to the evaluation of all government projects. This discount rate, as stipulated by the KDI, may not be optimal, considering Martinez-Paz et al. [28] findings following a survey of experts that discount rate for the first 30 years should in the range of $3.47 \%$, and $2.84 \%$ for the period between 30 and 50 years. However, the $5 \% / 6.5 \%$ rates in South Korea are required based on the KDI's analysis of the current and future trend of the Korean economy. 


\subsection{Analytic Hierarchy Process and Pairwise Comparison}

Saaty's AHP is based on the assumption that when faced with a complex decision, the natural human reaction is to cluster the criteria according to their common characteristics. It involves building a hierarchy of criteria and then making comparisons between each possible pair in each cluster [27,29-32]. A pairwise comparison method between the various criteria (surface water, groundwater, and geologic information) is used to assign weights to the different criteria by using a questionnaire (Figure 3).

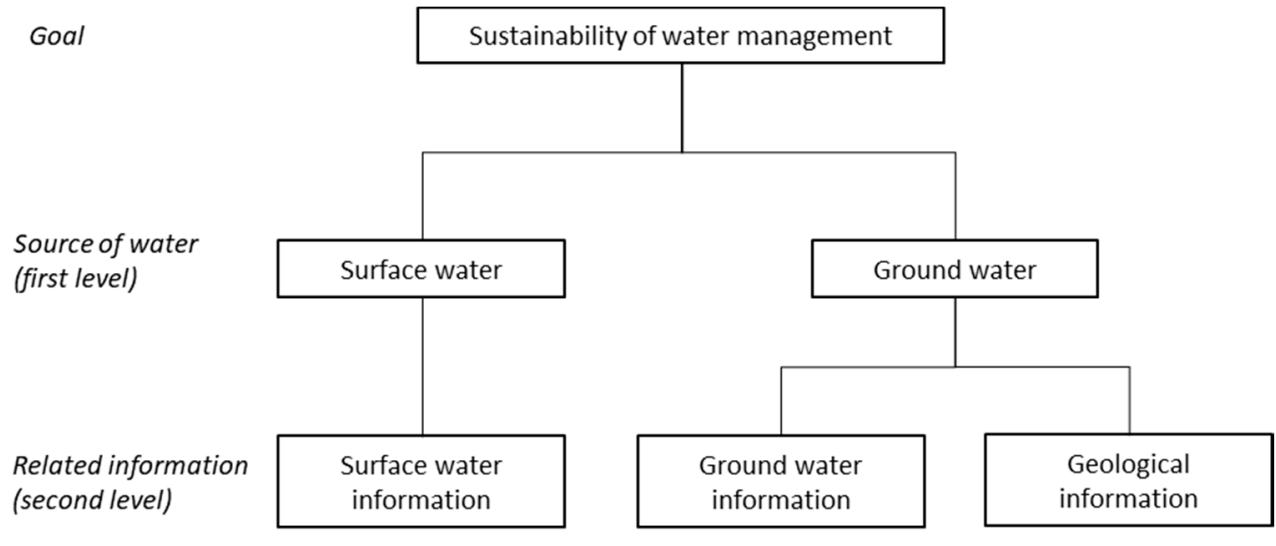

(a) The hierarchical value tree

Q1. Which source of water would be more important between surface water and groundwater for next 50 years in the aspect of economic use of national water resources in Korea?

\begin{tabular}{|c|c|}
\hline Surface water & $\bullet \bullet \bullet \bullet \bullet \bullet \bullet$ \\
\hline
\end{tabular}

Q2. Which of the following information would be more important to produce and supply the above water?
(1) Surface water information

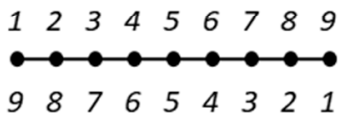
Ground water information
(2) Ground water

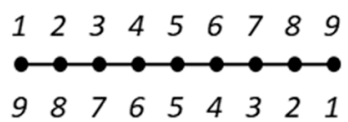
Geological information information
(3) Geological information

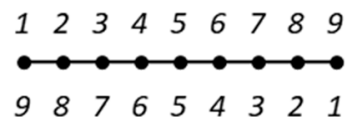
Ground water information

(b) AHP questionnaire

Figure 3. Cont. 


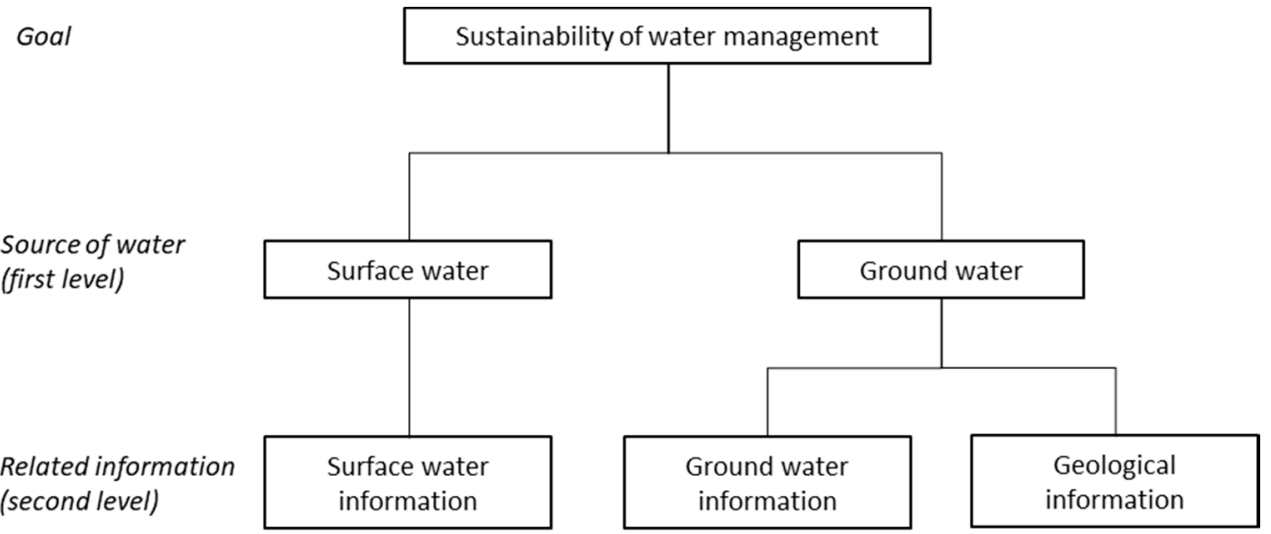

(c) The hierarchical value tree

Q1. Which source of water would be more important between surface water and groundwater for next 50 years in the aspect of economic use of national water resources in Korea?

\begin{tabular}{|c|c|c|}
\hline Surface water & $\bullet \bullet \bullet \bullet \bullet \bullet \bullet$ & Ground water \\
\hline
\end{tabular}

Q2. Which of the following information would be more important to produce and supply the above water?

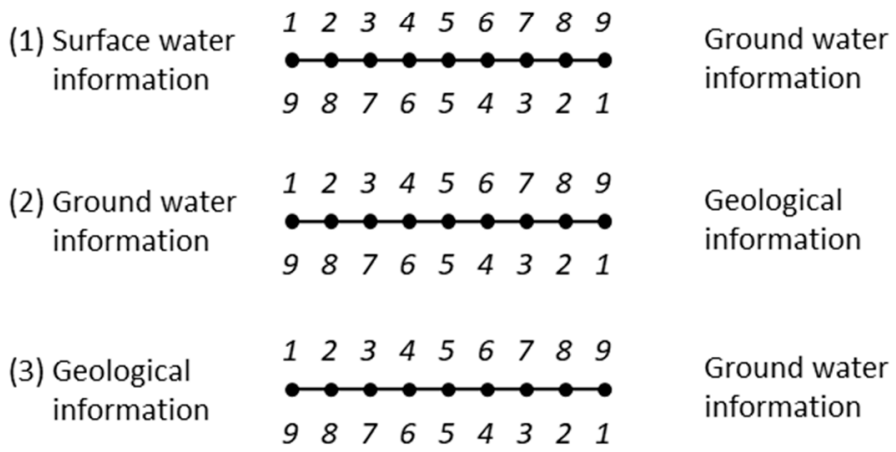

(d) AHP questionnaire

Figure 3. The hierarchical value tree and questionnaire for the AHP analysis.

Table 2. An example of a pairwise comparison process for the secondary three criteria [30].

\begin{tabular}{cccccc}
\hline Evaluation Criteria & A Criteria & B Criteria & C Criteria & Geometric Mean & Weights \\
\hline A criteria & 1 & $a_{12}$ & $a_{13}$ & $\sqrt[3]{\left(1 \times a_{12} \times a_{13}\right)}=\mathrm{GM}_{1}$ & $\mathrm{GM}_{1} / \mathrm{SumGM}$ \\
\hline B criteria & $\frac{1}{a_{12}}$ & 1 & $a_{23}$ & $\sqrt[3]{\left(\frac{1}{a_{12}} \times 1 \times a_{23}\right)}=\mathrm{GM}_{2}$ & $\mathrm{GM}_{2} / \mathrm{SumGM}$ \\
\hline C criteria & $\frac{1}{a_{13}}$ & $\frac{1}{a_{23}}$ & 1 & $\sqrt[3]{\left(\frac{1}{a_{12}} \times \frac{1}{a_{23}} \times 1\right)}=\mathrm{GM}_{3}$ & $\mathrm{GM}_{3} / \mathrm{SumGM}$ \\
\hline Total & & & $\mathrm{GM}_{1}+\mathrm{GM}_{2}+\mathrm{GM}_{3}=\mathrm{SumGM}$ \\
\hline
\end{tabular}

In order to compute the weights for the different criteria, the AHP starts creating a pairwise comparison matrix (Table 2) [30]. The geometric mean is an appropriate measure for combining individual judgments to obtain the group judgment for each pairwise comparison. The matrix is a $m \times m$ matrix, where $m$ is the number of evaluation criteria considered. The entries $a_{j k}$ and $a_{k j}$, which is a reciprocal of $a_{j k}$, satisfy the following constraint: 


$$
a_{j k} \cdot a_{k j}=1
$$

here, the entry $a_{j k}$ is the importance of the $j$ th criterion relative to the $k$ th criterion $[30,33]$.

Assuming that each $F_{j k}$ is independent, the score of each criterion obtained from the experts can be added together. Here, $F_{j k}$ is the $k$ th secondary criterion constituting the $j$ th primary evaluation criterion. The total score is produced by adding these $F_{j k}$ values and the mean of the total score $\left(M F_{j k}\right)$ can also be calculated from the total score. A pairwise comparison matrix for the secondary criteria with their relative values of importance can be produced. With the relative importance between the two criteria, geometric mean and weights were calculated (Table 2).

As described above, we use the relative values of importance to derive the benefit of groundwater monitoring networks.

To test a reliability of the AHP model with pairwise comparison, consistency index $\left\{C I=\frac{\left(\lambda_{\max }-n\right)}{(n-1)}\right\}$ and consistency ratio $(C R)$ are calculated. Consistency ratio indicates how far the pairwise judgements deviate from a purely random matrix of pairwise comparisons, and is defined as:

$$
C R=\frac{C I}{R I}
$$

where $R I$ is called random index [30].

Two water sources, surface water and groundwater, are conceptually different from geologic information, and it is not easy to compare them to it because their policy fields, economic aspects, and expected effects are different. Therefore, multiple and diverse discussion on their concepts and effects based on some indicators explaining their characteristics is required to derive the relative importance between them. For a better discussion and understanding, the detailed indicators corresponding to the meanings of the information are derived from previous research and summarized systematically $[4,12,26,34]$. Subsequently, such research results were provided to the respondents of the questionnaire (Table 3). Consequently, a relative value of importance between the geological, groundwater, and surface water information is assessed by reviewing the provided indicators and comparing those values with the well-defined benefits of geologic information. In previous research, the benefits of information in surface water, groundwater, and geology consist of some selective indicators, as summarized in (Table 3).

Table 3. Some selective indicators used for comparing the benefits of information in surface water,

\begin{tabular}{|c|c|c|c|}
\hline Indicators & Surface Water & Groundwater & Geology ** \\
\hline Policy aspect & $\begin{array}{l}\text { - } \quad \text { Governmental (long term) plan and } \\
\text { future requirements } \\
\text { - } \quad \text { Water supply (Domestic, Industrial, } \\
\text { Agricultural)* } \\
\text { - } \quad \text { Flood/drought control * } \\
\text { - } \quad \text { Restoration of natural resources * } \\
\text { - Ecological diversity }\end{array}$ & $\begin{array}{ll}\text { - } & \text { Governmental (long term) plan and } \\
\text { future requirements } \\
\text { - } & \text { Water supply (Domestic, Industrial, } \\
\text { - } & \text { Agricultural)* } \\
\text { - } & \text { Resought control * } \\
\text { - } & \text { Ecological diversity }\end{array}$ & 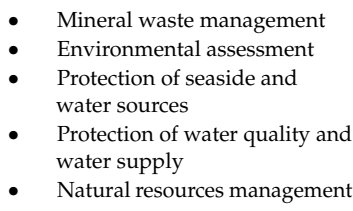 \\
\hline Economic aspect & $\begin{array}{l}\text { - } \quad \text { Electricity production * } \\
\text { - } \quad \text { Cost (Production, Water treatment, } \\
\text { Supply, Management)* } \\
\text { - } \quad \text { Transportation (Canal) * }\end{array}$ & $\begin{array}{l}\text { - } \text { Geothermal source } \\
\text { - Cost (Production, Water treatment, } \\
\text { Supply, Management)* }\end{array}$ & $\begin{array}{l}\text { - } \quad \text { Mineral production } \\
\text { - } \quad \text { Covelopment of local region } \\
\quad \text { railway, port, building, etc.) }\end{array}$ \\
\hline User aspect & $\begin{array}{l}\text { - Agricultural/industrial productivity } \\
\text { - } \\
\text { - } \\
\text { - } \\
\text { Lecrea and use }{ }^{*}\end{array}$ & $\begin{array}{l}\text { - } \quad \text { Agricultural/industrial productivity } \\
\text { - } \quad \text { User accessibility } \\
\text { - } \quad \text { Land use * } \\
\text { Water welfare }\end{array}$ & $\begin{array}{ll}\text { - } & \text { Real estate and insurance } \\
\text { - } & \text { Health } \\
\text { - } & \text { Education and Research } \\
\text { - } & \text { Agriculture/Forism } \\
& \text { Agrions }\end{array}$ \\
\hline
\end{tabular}
groundwater and geology $[4,12,21,26,32]$. 
Table 3. Cont.

\begin{tabular}{clll}
\hline Indicators & \multicolumn{1}{c}{ Surface Water } & \multicolumn{1}{c}{ Groundwater } \\
\hline & & Economic benefit* & Geogy \\
Others & $\bullet$ & Future value & Economic benefit* \\
& $\bullet$ & Emergency use & Future value \\
& & & Emergency use
\end{tabular}

Note: (1) Asterisks $\left(^{*}\right)$ denote items of water benefit proposed by the KDI (2008) [26] and ${ }^{* *}$ denotes items of geology benefit proposed by the BGS; (2) Some of the above indicators are also discussed in Marcouiller and Coggins (1999) [34], Ellison and Calow (1996) [12], and Environment Agency (2007) [4].

\section{Cost and Benefit of Groundwater Monitoring Networks}

\subsection{Cost}

The costs of the groundwater monitoring network are determined according to the facility design, maintenance strategy, repair, and reinstallation (Table 4). The design of a groundwater monitoring well depends on the purpose of each monitoring system. For example, the SIMN should have an electric conductivity sensor to detect sea-water intrusion, and the GQMN and the NGMN should have an automatic monitoring system for groundwater quality and quantity measurements. Construction and installation costs of the monitoring networks include a well drilling and remote terminal system and power battery. Maintenance costs include the replacement of old wells and all devices. Service costs include labor charges for replacement and maintenance, and travel expenses for collecting water samples (Table 4).

According to the Groundwater Promotion Act, the owner should report the end of groundwater use to the local government when both closing and drilling a well. By using the national statistics of this data on groundwater wells (www.gims.go.kr), 217,993 pumping wells, which were drilled during the period from 1970 to 1989, are analyzed to calculate their average life cycle (Figure 4). The average life cycle is calculated to be 29.7 years for their periods in service, where the equation is "service period = year of construction - year of removal +1 ". Considering the structural similarity of monitoring and pumping wells, the life cycle of groundwater monitoring wells are also considered to be 29.7 years, with the exception of a sensor and telemetering device with a shorter life cycle (Table 4). By using the above installation data and maintenance plan, the costs for each monitoring network for the period 2011-2060 are finally calculated with the total costs amounting to USD 793.6 million. The cost details by type of network are listed below (Table 5).

Table 4. Unit costs of construction and management for groundwater monitoring networks.

\begin{tabular}{|c|c|c|}
\hline Type of Network & $\begin{array}{l}\text { Items and Unit Costs } \\
\text { (unit: USD/single well) }\end{array}$ & Remarks \\
\hline NGMN & $\begin{array}{ll}\text { - } & \text { Construction/drilling: } 39,965 \\
\text { - } & \text { Equipment installation: } 11,182 \\
\text { - } & \text { Service: } 5386 \\
\text { - } & \text { RTU replacement: } 3516 \\
\text { - } & \text { Battery replacement: } 111\end{array}$ & $\begin{array}{l}\text { - Service includes labor, travel cost, water } \\
\text { analysis fee, reporting, etc. } \\
\text { RTU: Remote terminal unit for data collection } \\
\text { and transmission ( } 11 \% \text { of wells are replaced } \\
\text { every year) }\end{array}$ \\
\hline SGMN & $\begin{array}{ll}\text { - } & \text { Reuse of existing well(Manual } \\
\text { - } & \text { installation): } 30 \\
\text { - } & \text { Rell installation: } 14,567 \\
\text { - } & \text { Service(manual): } 713 \\
\text { - } & \text { Service(automatic): } 2825 \\
\text { - } & \text { Equipment replacement: } 65\end{array}$ & $\begin{array}{l}\text { - } \quad \text { Reuse means the existing well is used as a } \\
\text { monitoring well } \\
\text { - Well installation means new well drilling } \\
\text { - Service (manual) includes sampling, reporting } \\
\text { and water level measuring } \\
\text { - Service (automatic) means automatic } \\
\text { measurements of water level and quality } \\
\text { sensors as well as sampling and reporting }\end{array}$ \\
\hline
\end{tabular}


Table 4. Cont

\begin{tabular}{|c|c|c|}
\hline Type of Network & $\begin{array}{l}\text { Items and Unit Costs } \\
\text { (unit: USD/single well) }\end{array}$ & Remarks \\
\hline GMFA & $\begin{array}{ll}\text { - } & \text { Construction/drilling: } 40,030 \\
\text { - } & \text { Equipment installation: } 767 \\
\text { - } & \text { Service: } 4612 \\
\text { - } & \text { Replacement (Device and Battery): } 4744\end{array}$ & $\begin{array}{l}\text { - Service includes management, sampling, } \\
\text { manual measurements of level, reporting, etc. } \\
\text { Equipment includes water level sensor, logger } \\
\text { and telemetering }\end{array}$ \\
\hline SIMN & $\begin{array}{ll}\text { - } & \text { Construction/drilling: } 42,031 \\
\text { - } & \text { Equipment installation: } 10,465 \\
\text { - } & \text { Service: } 674 \\
\text { - } & \text { Replacement (Device and Battery): } 3633\end{array}$ & $\begin{array}{l}\text { - } \quad \text { Equipment includes water level and quality } \\
\text { sensors as well as telemetering } \\
\text { - Service includes sampling, water analysis, } \\
\text { reporting, and level measurement }\end{array}$ \\
\hline GQM & $\begin{array}{ll}\text { - } & \text { GQMN construction/drilling: 78,761 } \\
\text { - } & \text { GPMN construction: } 2902 \\
\text { - } & \text { GQMN labor and travel: } 383 \\
\text { - } & \text { EPMN labor and travel: } 43 \\
\text { - } & \text { Water sample(Fee): } 1104 \\
\text { - } & \text { Water sample(Labor): } 58\end{array}$ & $\begin{array}{l}\text { - GQMN uses a new well and GPMN uses an } \\
\text { existing well } \\
\text { Labor and travel costs are needed for sampling, } \\
\text { level measurement, etc. GQMN labor cost is } \\
\text { high due to equipment inspection }\end{array}$ \\
\hline LQMN & $\begin{array}{ll}\text { - } & \text { Reuse of existing well: } 172 \\
\text { - } & \text { Service(labor and travel): } 128 \\
\text { - } & \text { Water sample(Fee): } 128 \\
\text { - } & \text { Water sample(Labor): } 51\end{array}$ & $\begin{array}{l}\text { Equipment replacement includes well } \\
\text { protection apparatus, guide plate, etc. }\end{array}$ \\
\hline
\end{tabular}

Note: 1 US $\$=1100$ Korean Won.

Table 5. Present values of total costs for each type of groundwater monitoring network for 50 years (Appendix A).

\begin{tabular}{|c|c|c|c|c|c|c|}
\hline \multicolumn{2}{|c|}{ Type } & $\begin{array}{l}\text { Construction, Installation, } \\
\text { \& Well Replacement }\end{array}$ & $\begin{array}{l}\text { Maintenance } \\
\text { \& Service }\end{array}$ & $\begin{array}{c}\text { Device } \\
\text { Replacement }\end{array}$ & $\begin{array}{l}\text { Water Sample } \\
\text { Test * }\end{array}$ & Total \\
\hline \multicolumn{2}{|c|}{ NGMN } & $7,528,404$ & $70,758,976$ & $3,908,395$ & - & $82,195,775$ \\
\hline \multirow{2}{*}{ SGMN } & Manual & 386,490 & $61,253,235$ & 17,619 & - & \multirow{2}{*}{$246,177,391$} \\
\hline & Automatic & $80,570,577$ & $103,922,130$ & 27,340 & - & \\
\hline \multicolumn{2}{|c|}{ GMFA } & $37,086,424$ & $126,068,647$ & $8,140,240$ & - & $171,295,311$ \\
\hline \multicolumn{2}{|c|}{ SIMN } & $10,449,325$ & $48,662,609$ & $2,716,363$ & - & $61,828,297$ \\
\hline \multirow{2}{*}{ GQM } & $\begin{array}{l}\text { Quality } \\
\text { (GQMN) }\end{array}$ & $63,072,618$ & $6,109,509$ & \multirow{2}{*}{595,225} & \multirow{2}{*}{$33,989,889$} & \multirow{2}{*}{$108,164,812$} \\
\hline & $\begin{array}{l}\text { Pollution } \\
(\text { GPMN) }\end{array}$ & $3,427,972$ & 969,599 & & & \\
\hline \multicolumn{2}{|c|}{ LQMN } & $52,744,882$ & $15,300,180$ & $3,906,735$ & $51,989,311$ & $123,941,108$ \\
\hline \multicolumn{6}{|c|}{ Total } & $793,602,694$ \\
\hline
\end{tabular}

Notes: (1) Maintenance and service costs include fees for water sample tests for NGMN (National Groundwater Monitoring Network), SGMN (Subsidiary Groundwater Monitoring Network), GMFA (Groundwater Monitoring Network in Farming Areas), and SIMN (Seawater Intrusion Monitoring Network); (2) According to KDI (2008) [26], two discount rates of $5.0 \%$ for the initial 30 years and $6.5 \%$ for the next 20 years are used to calculate net present values.

\subsection{Benefits}

Each groundwater monitoring network has its own objective function, and therefore, the benefits can be different from each other. However, some of their functions, such as the measurement of groundwater level and basic quality observations, overlap for each network. For example, the NGMN and the SIMN have a similar purpose regarding water level observation, but the SIMN is more beneficial in protecting against seawater intrusion along the coastal line. Additionally, because the benefits of the monitoring networks include both use value and passive value, it is not easy to quantify as mentioned in the above section. Therefore, it is almost impossible to calculate the value of each monitoring network separately, and in this study the benefits are assessed for the whole network based on the network's conceptual average benefits by being compared with the geological information. 
When applying the AHP for the benefit estimation, a series of intensive discussions with groundwater and geology specialists in South Korea were conducted by reviewing some indicators for comparison in order to determine the primary and secondary criteria. A hierarchical value tree using the primary and secondary criteria for an assessment of groundwater value was finally proposed

To evaluate the value of groundwater information, a questionnaire survey was made to estimate the relative value of groundwater information compared with surface water and geological information as the second criteria, and also the relative importance of groundwater and surface water as the first criteria considering the proposed indicators. A total of 55 questionnaires were collected from hydrogeologists, surface water specialists and geologists. Interview participants were provided with the monetary value of geological mapping as estimated by Kim et al. [17]. Through several brainstorming sessions, all specialist participants were asked to respond to the relative economic value of groundwater information compared with geological mapping which is estimated to be USD 964.8 million. Therefore, they knew that if one answered " 1 " for geological information and " 2 " for groundwater information in the Likert scales, it meant that the monetary value of groundwater information was 2 times greater than that of geological information for the person.

The survey results show that the value of surface water information is 2.37 times more important than geological information, and groundwater information is 2.39 times greater than that of geological information (Table 6). The consistency index is 0.005 and random index is 0.58 . The calculated consistency ratio is nearly zero, i.e., 0.009 . Because Saaty's rule of thumb is to allow up to $10 \%$ inconsistency within the random matrix, this level of consistency is satisfactory.

Table 6. Relative values of groundwater information estimated by the AHP with pairwise comparison.

\begin{tabular}{cccc}
\hline Item & $\begin{array}{c}\text { Surface Water } \\
\text { Information/Groundwater } \\
\text { Information }\end{array}$ & $\begin{array}{c}\text { Surface Water } \\
\text { Information/Geological } \\
\text { Information }\end{array}$ & $\begin{array}{c}\text { Groundwater } \\
\text { Information/Geological } \\
\text { Information }\end{array}$ \\
\hline Value & 0.72 & 2.37 & 2.39 \\
\hline
\end{tabular}

Applying the BGS model, Kim et al. [10] calculates the value of geological information (1:50,000 scale maps) [12]. In total, seven sectors are considered in estimating the benefits of geological information: mineral products, waste facility construction, environmental impact, groundwater relations, regional development, coastal management, and social infrastructure (Table 7). The total annual benefits of Korean geological information are estimated as USD 56.6 million. Consequently, the total benefits of geological information for 50 years are calculated by multiplying and discounting the annual benefit based on the KDI guidelines such as the discount rate. Finally, the benefits for geological information in South Korea are estimated as USD 964.8 million.

The relative value of groundwater information provided by the monitoring networks, which means ultimately the benefit of the networks, can be estimated by multiplying the value of geological information by the relative importance value, 2.39, of groundwater information (Table 6). Therefore, the benefit of the monitoring networks can be estimated to be about USD 2314.7 million. 
Table 7. Estimation of total annual benefits of geological information in South Korea [12,16].

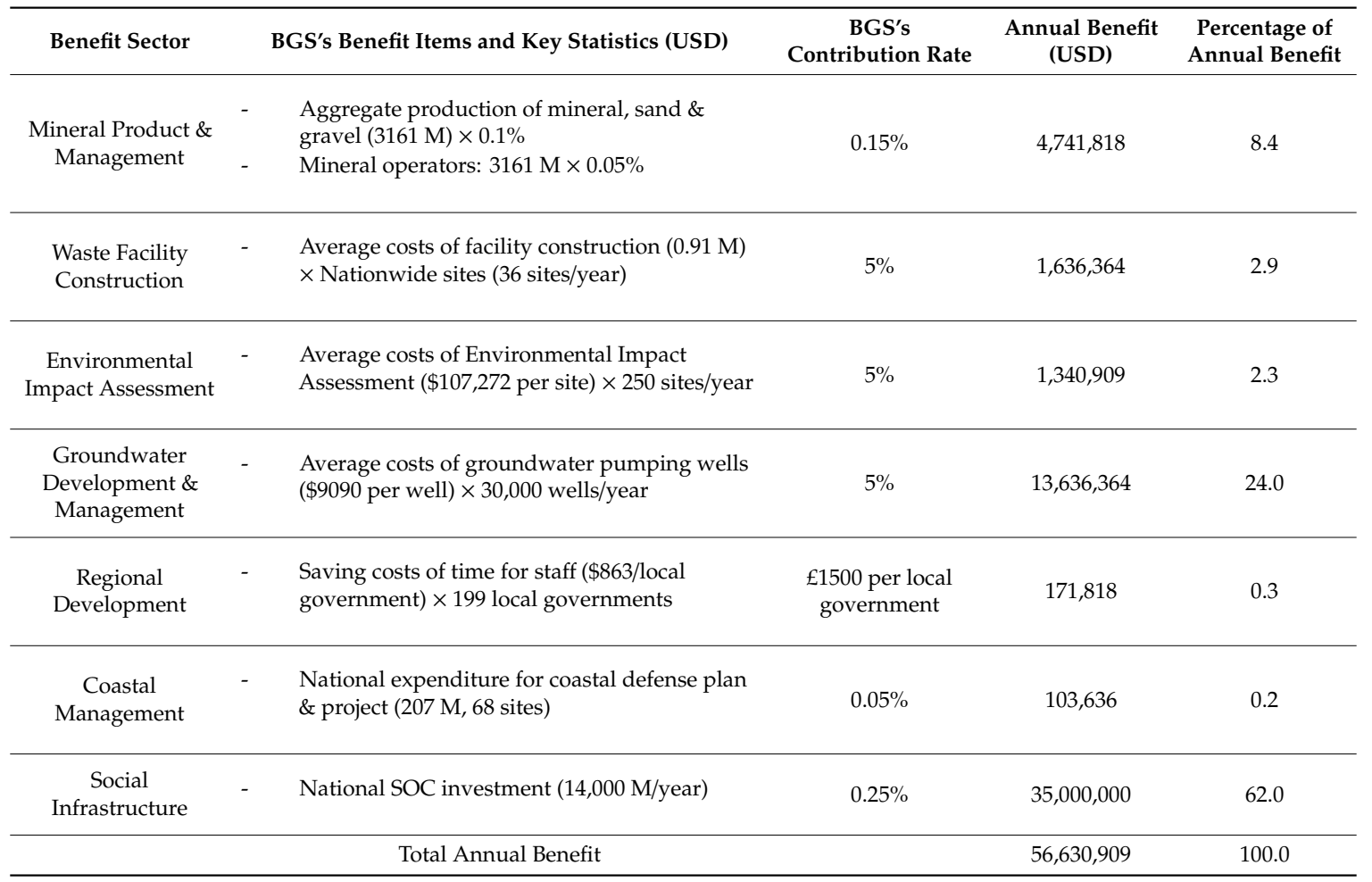

Based on interviews with geotechnical specialists, Ellison and Calow [12] argued that geological mapping information is worth at least $25 \%$ of the value of the site investigation, and considerably more where modern maps and databases are available to enable better decision making and risk assessment to be made. According to Kim et al. [17], the annual average costs for geological site investigation take $1 \%$ of the total expenditure of national SOC investment in Korea. We understand that Kim et al. [17] calculated the benefits by multiplying $25 \% \times 1 \% \times$ SOC investment, hence the $0.25 \%$ National SOC expenditure rate for social infrastructure.

\section{Results and Sensitivity Test}

As mentioned above, the cost of the groundwater monitoring network over the next 50 years is estimated to be USD 793.6 million in present value terms. Meanwhile, the present value of benefit obtained by the AHP analysis has a value of USD 2314.7 million. The BC ratio of the groundwater monitoring network is therefore 2.91 , and thus the monitoring network's benefits will greatly exceed the costs over the next 50 years. This high ratio means that the expansion of the existing groundwater monitoring networks is a highly economical solution of great value to an essential issue.

The original trends of the estimated costs and benefits of groundwater monitoring networks, which are calculated through the above process, are plotted in Figure 4. 


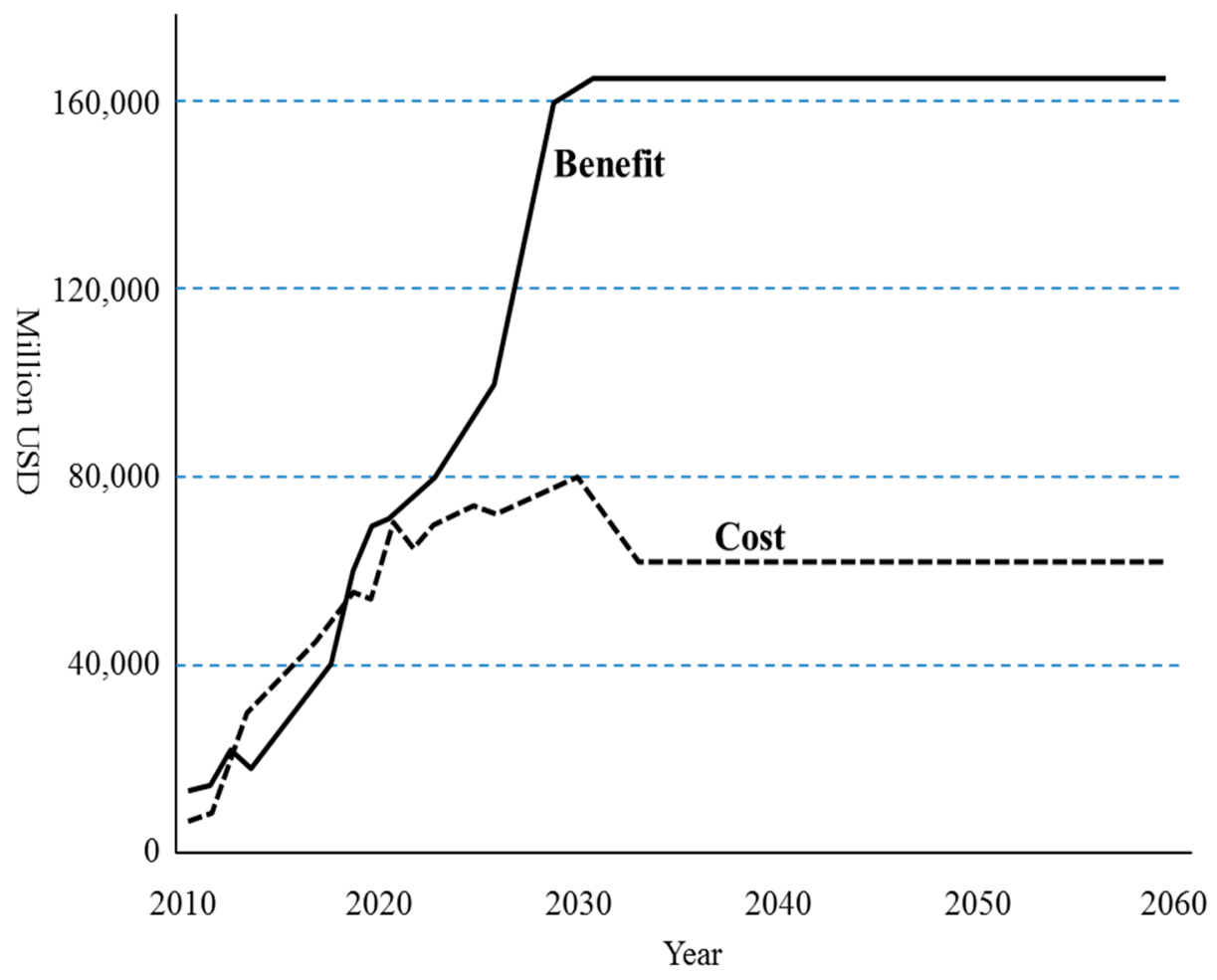

Figure 4. Long-term comparison of benefits and costs of the groundwater monitoring networks.

The trends indicate that the benefits and the costs will increase by almost the same ratio until 2020, but the gap between benefits and costs grows annually after 2020 and until 2030, when the new constructions are fully installed as scheduled.

Future costs and benefits, on which the net present value is based, are predicted values with uncertainty. Therefore a sensitivity test is required to confirm the result and it is important to test the values under both 'optimistic' and 'pessimistic' scenario conditions. If the output values are shown to be very sensitive to changes in a given input value, the model should be checked for the appropriateness and impact of the given variable. The government schedule for the number of monitoring wells is a key point for the cost calculation and therefore additional BC analysis is performed again under the condition of a changed schedule, which means a delay of network installation, in calculating the BC ratio for a sensitivity test.

We run simple OLS (Ordinary Least Square) regressions to project the number of monitoring wells for the target year 2060, based on the previous installation trends, from the late 1990s to 2012, of six different networks (Figure 5). As a result of these regressions, by 2060 we estimate the number of wells by type as following: NGMN 530; SGMN 3977; LQMN 3149; SIMN 388; GMFA 347; and GQM 231. However, in cases of the NGMN and the SIMN, the original target numbers, 530 and 388 , will be accomplished in 2018 and 2038 (Appendix B). 


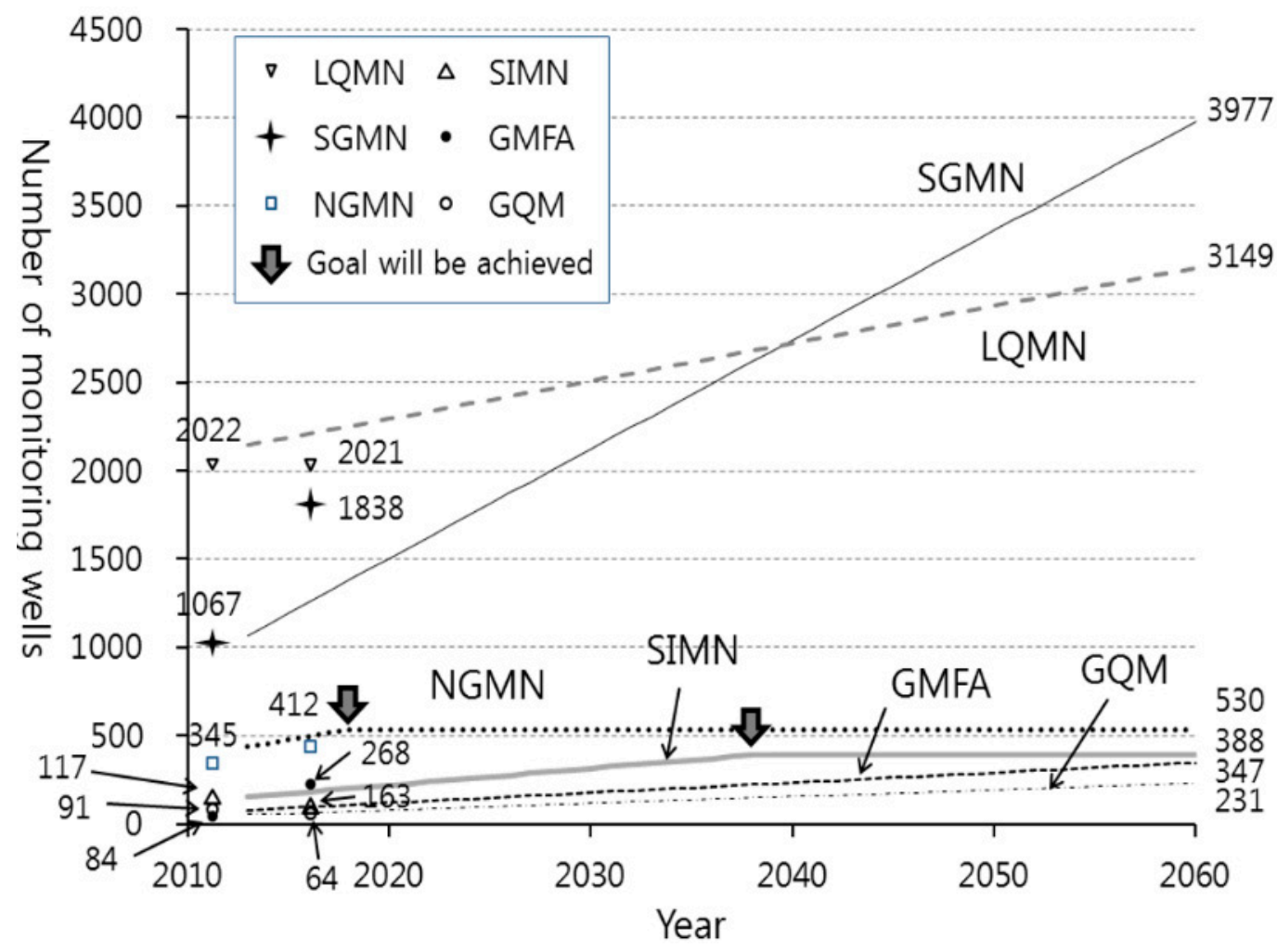

Figure 5. Forecasting groundwater monitoring networks considering recent trends. Note: Symbols denote numbers of groundwater monitoring wells in 2011 and 2016.

Considering these trends, the costs of the networks are recalculated with the same process, becoming about USD 265.6 million, or $33.4 \%$ of the total costs. On the other hand, this total number of monitoring wells, 8622 , reaches only $17.8 \%$ of the planned number of 48,443 . Following the previous trends of the above 6 types of wells as shown in Figure 5, we found that the reduction rates of both cost and numbers of wells are not proportionate because lower cost wells such as LQMN and SGMN take over $88 \%$ of the total number of wells. This is why the rate of cost reduction is much smaller than that of the number of wells reduced.

On the other hand, the benefits, in proportion to the number of wells, should be reduced to $17.8 \%$, or USD 412.0 million, of the original total benefits. This indicates that the $\mathrm{BC}$ ratio is drastically reduced from 2.91 to 1.55 (= USD 412.0 million over USD 265.6) and it means the ratio, which will have decreased by about $47 \%$, is relatively less sensitive than the reduced percentage of the number of monitoring wells ( $82 \%)$. Although the $\mathrm{BC}$ ratio is reduced, it is noteworthy that the benefits still outweigh the costs and the value of groundwater monitoring exists still. This result shows that new installations should continue to be made even if the number of monitoring wells remains below the planned target (Table 8).

Table 8. Results and sensitivity test.

\begin{tabular}{cccc}
\hline Scenarios & Benefit (1000 USD) & Cost (1000 USD) & B/C Ratio \\
\hline Groundwater project & $2,314,782$ & 793,602 & 2917 \\
\hline Past trend & 412,031 & 265,642 & 1551 \\
\hline
\end{tabular}

In 2016, the numbers of monitoring networks become 412, 1838, 268, 64, 2021, and 163 for the NGMN, the SGMN, the GMFA, the GQM, the LQMN, and the SIMN, respectively (Figure 5). In the cases of the NGMN, the LQMN, and the SIMN, the actual installation does not meet the target number but the other networks have been installed over the predicted number as of 2016. The recent trend is 
roughly similar to the past trend from the late 1990s to 2012 and so it is still economical. Even though the recent trend of monitoring well installation may change according to the budget or national policy, it is shown that the continuous installation is important and valuable.

\section{Conclusions and Discussion}

Especially in water-stressed countries, water authorities have been struggling to design policies that address emerging physical, economic and environmental stress on groundwater resources. In order to contribute to policy discussion, we suggest some basic indicators and a framework, based on the BGS' and the USGS's models of groundwater, for measuring the costs and benefits of groundwater information. For our model, we have assumed, on the basis of Kim et al. [17], who based their calculations on Ellison and Calow [12], that benefits are equal to $25 \%$ of National SOC expenditure, which they claim to be on the conservative side and may in truth be more where more detailed and up-to-date maps and databases are used. However, our research goal was to introduce a viable model with which to estimate and analyze the costs involved in building and maintaining the monitoring networks and the various benefit streams expected from them. As shown above, the review of previous research shows significant economic benefits attached to the generation of this type of geological and groundwater information. It is, however, difficult to compare results across studies since they differ in scope and make assumptions regarding which sectors to cover. As much research has verified that benefit-cost ratio of geological information were much greater than one, this analysis of groundwater monitoring networks in South Korea also shows that the benefits are greater than the costs, and demonstrates the economic feasibility of the planned network project in the national groundwater master plan as promoted by the government. Groundwater information, which plays a key role in addressing the challenges of sustainable water supply, contributes to improved decision making processes.

One of the limitations of our research is that we apply the indirect method of estimation by calculating the relative value of groundwater monitoring networks through questionnaire. It is difficult to express the benefit of groundwater information, which is a public good, in monetary terms, because of the limited availability of the necessary information since its market price does not exist. Even more, the benefit assessment is complex due to different spatial and temporal scales on which many of the benefits of the groundwater information operate. This is the main reason why the benefit of each monitoring network cannot be measured separately.

The second limitation of our research is that our valuation of groundwater information, which considers a scope of 50 years, might be recalculated due to the currently unknown effects of climate change in the future, which has been linked to changes in the large-scale hydrological cycle in the long run. We expect that the most significant abnormal weather phenomenon due to climate change is the change of water circulation. Previous studies indicated that greenhouse gases accelerate global warming, resulting in an increase of moisture in the air which strengthens the water circulation process. The long-term change in the rainy season in the Korean peninsula has been studied in many aspects. According to Ryoo [35], comparing precipitation from the 1960s to that of the past 30 years during the rainy season, the number of precipitation days has decreased from 62 percent in the 1960s to 56 percent in the past 30 years. With higher than average temperatures and warmer air that can hold, a pattern might emerge of lengthy dry spells interspersed with brief but heavy precipitation and possible flooding in Korea. Indeed, Ryoo [35] concluded that sudden precipitation causing a greater likelihood of flooding is expected in the future, which would cause instability in surface water supply. Thus groundwater represents a reasonable reliable source of water under such an eventuality. Therefore, because much of the impact of climate change will be felt through changing patterns of water availability [36], groundwater resources are an essential source of water, especially for water-stressed and highly surface-water dependent countries like Korea in the future. In this respect, further research incorporating the factor of climate change in the long-time would be valuable to establish the water management capability on a sustainable basis. 
Lastly, we did not discuss the environmental costs of groundwater as Martinez-Paz et al. [25] studied. They concluded that the environmental and resource costs as a result of depletion and degradation of groundwater were $0.454 € / \mathrm{m}^{3}$ including the price of the services provided by the groundwater of an aquifer in Spain. As Korea currently uses about 3500 million tons of groundwater as of 2018, the costs would be 1589 million $€$ according to Martinez-Paz's study, which is approximately the same as the benefit we estimated above. However, their costs include the opportunity cost for recreation which may not occur in many groundwater pumping well sites in Korea because $57.2 \%$ of pumping wells are being used by households.

The government generally requires an economic validation of a new project. In particular, it is very difficult to explain or quantitatively calculate the importance of a new groundwater project because it is associated with many unknown variables such as hydraulic uncertainties and environmental forecasts such as climate change. This study represents a simple solution with an economic approach for the groundwater monitoring system providing groundwater information, which is a BC analysis and AHP with a pairwise comparison, which will be useful to decision-makers within water authorities not only in Korea but in water-stressed countries throughout the world.

Author Contributions: Data curation, G.-B.K.; Formal analysis, S.G.K.; Funding acquisition, S.G.K.; Investigation, G.-B.K.; Methodology, S.G.K.; Project Administration, S.G.K.; Resources, G.-B.K.; Software, G.-B.K.; Supervision, S.G.K.; Validation, S.G.K.; Writing-original draft, S.G.K.; and Writing-review \& editing, S.G.K.

Funding: This research was funded by Daejeon University.

Conflicts of Interest: The authors declare no conflict of interest.

\section{Appendix A}

Table A1. Cost detail of the NGMN (unit: USD).

\begin{tabular}{|c|c|c|c|c|c|c|c|c|c|c|}
\hline \multirow[b]{2}{*}{ Year } & \multirow[b]{2}{*}{ NGMN } & \multicolumn{2}{|c|}{ Construction } & \multirow[b]{2}{*}{ Installation } & \multirow[b]{2}{*}{ Service } & \multicolumn{3}{|c|}{ Replacement } & \multirow{2}{*}{$\begin{array}{c}\text { GDP } \\
\text { Deflator * }\end{array}$} & \multirow[b]{2}{*}{$\begin{array}{l}\text { Discount } \\
\text { Rate }\end{array}$} \\
\hline & & Plan & Cost & & & $\begin{array}{c}\text { Number of } \\
\text { RTU }\end{array}$ & RTU & Battery & & \\
\hline 2011 & 345 & 10 & 399,650 & 111,818 & $1,858,274$ & 44 & 154,736 & 4886 & 101.8 & \\
\hline 2012 & 355 & 10 & 382,609 & 111,818 & $1,637,538$ & 40 & 145,920 & 4608 & 105.6 & \\
\hline 2013 & 365 & 10 & 390,846 & 111,818 & $1,657,199$ & 52 & 194,007 & 6127 & 108.0 & \\
\hline 2014 & 386 & 21 & 895,369 & 254,610 & $2,215,742$ & 85 & 322,744 & 10,192 & 110.4 & \\
\hline 2015 & 406 & 21 & 914,834 & 260,145 & $2,466,026$ & 66 & 255,723 & 8075 & 112.8 & \\
\hline 2016 & 427 & 21 & 934,298 & 265,680 & $2,730,069$ & 58 & 229,327 & 7242 & 115.2 & \\
\hline 2017 & 448 & 21 & 953,763 & 271,215 & $3,007,910$ & 41 & 165,041 & 5212 & 117.6 & \\
\hline 2018 & 468 & 21 & 973,227 & 276,750 & $3,299,584$ & 43 & 176,700 & 5580 & 120.0 & \\
\hline 2019 & 489 & 21 & 992,692 & 282,285 & $3,605,124$ & 62 & 260,573 & 8229 & 122.4 & \\
\hline 2020 & 509 & 21 & $1,012,157$ & 287,820 & $3,947,797$ & 65 & 278,616 & 8798 & 124.8 & \\
\hline 2021 & 530 & 21 & $1,031,621$ & 293,355 & $4,283,300$ & 61 & 266,397 & 8413 & 127.2 & \\
\hline 2022 & 530 & & & & $4,283,300$ & 52 & 232,809 & 7352 & 129.6 & \\
\hline 2023 & 530 & & & & $4,283,300$ & 85 & 385,890 & 12,186 & 132.0 & \\
\hline 2024 & 530 & & & & $4,283,300$ & 66 & 304,691 & 9622 & 134.4 & \\
\hline 2025 & 530 & & & & $4,283,300$ & 58 & 272,325 & 8600 & 136.8 & $6.5 \%$ \\
\hline 2026 & 530 & & & & $4,283,300$ & 41 & 195,355 & 6169 & 139.2 & \\
\hline 2027 & 530 & & & & $4,283,300$ & 43 & 208,506 & 6584 & 141.6 & \\
\hline 2028 & 530 & & & & $4,283,300$ & 62 & 306,556 & 9681 & 144.0 & \\
\hline 2029 & 530 & & & & $4,283,300$ & 65 & 326,838 & 10,321 & 146.4 & \\
\hline 2030 & 530 & & & & $4,283,300$ & 61 & 311,635 & 9841 & 148.8 & \\
\hline 2031 & 530 & & & & $4,283,300$ & 52 & 271,610 & 8577 & 151.2 & \\
\hline 2032 & 530 & & & & $4,283,300$ & 85 & 449,328 & 14,189 & 153.7 & \\
\hline 2033 & 530 & & & & $4,283,300$ & 66 & 353,886 & 11,175 & 156.1 & \\
\hline 2034 & 530 & & & & $4,283,300$ & 58 & 315,523 & 9964 & 158.5 & \\
\hline 2035 & 530 & & & & $4,283,300$ & 41 & 225,809 & 7131 & 160.9 & \\
\hline 2036 & 530 & & & & $4,283,300$ & 43 & 240,459 & 7593 & 163.3 & \\
\hline 2037 & 530 & & & & $4,283,300$ & 62 & 352,753 & 11,140 & 165.7 & \\
\hline 2038 & 530 & & & & $4,283,300$ & 65 & 375,283 & 11,851 & 168.1 & \\
\hline 2039 & 530 & & & & $4,283,300$ & 61 & 357,081 & 11,276 & 170.5 & \\
\hline 2040 & 530 & & & & $4,283,300$ & 52 & 310,591 & 9808 & 172.9 & \\
\hline
\end{tabular}


Table A1. Cont.

\begin{tabular}{|c|c|c|c|c|c|c|c|c|c|c|}
\hline \multirow[b]{2}{*}{ Year } & \multirow[b]{2}{*}{ NGMN } & \multicolumn{2}{|c|}{ Construction } & \multirow[b]{2}{*}{ Installation } & \multirow[b]{2}{*}{ Service } & \multicolumn{3}{|c|}{ Replacement } & \multirow{2}{*}{$\begin{array}{c}\text { GDP } \\
\text { Deflator * }\end{array}$} & \multirow{2}{*}{$\begin{array}{l}\text { Discount } \\
\text { Rate * }\end{array}$} \\
\hline & & Plan & Cost & & & $\begin{array}{c}\text { Number of } \\
\text { RTU }\end{array}$ & RTU & Battery & & \\
\hline 2041 & 530 & & & & $4,283,300$ & 85 & 512,474 & 16,183 & 175.3 & \\
\hline 2042 & 530 & & & & $4,283,300$ & 66 & 402,854 & 12,722 & 177.7 & \\
\hline 2043 & 530 & & & & $4,283,300$ & 58 & 358,522 & 11,322 & 180.1 & \\
\hline 2044 & 530 & & & & $4,283,300$ & 41 & 256,122 & 8088 & 182.5 & \\
\hline 2045 & 530 & & & & $4,283,300$ & 43 & 272,265 & 8598 & 184.9 & \\
\hline 2046 & 530 & & & & $4,283,300$ & 62 & 398,736 & 12,592 & 187.3 & \\
\hline 2047 & 530 & & & & $4,283,300$ & 65 & 423,505 & 13,374 & 189.7 & \\
\hline 2048 & 530 & & & & $4,283,300$ & 61 & 402,319 & 12,705 & 192.1 & \\
\hline 2049 & 530 & & & & $4,283,300$ & 37 & 248,606 & 7851 & 194.5 & \\
\hline 2050 & 530 & & & & $4,283,300$ & 48 & 323,945 & 10,230 & 196.9 & $5.0 \%$ \\
\hline 2051 & 530 & & & & $4,283,300$ & 21 & 142,001 & 4484 & 199.3 & $0.0 \%$ \\
\hline 2052 & 530 & & & & $4,283,300$ & 21 & 143,711 & 4538 & 201.7 & \\
\hline 2053 & 530 & & & & $4,283,300$ & 21 & 145,493 & 4595 & 204.2 & \\
\hline 2054 & 530 & & & & $4,283,300$ & 28 & 197,162 & 6226 & 206.6 & \\
\hline 2055 & 530 & & & & $4,283,300$ & 29 & 206,673 & 6527 & 209.0 & \\
\hline 2056 & 530 & & & & $4,283,300$ & 31 & 223,652 & 7063 & 211.4 & \\
\hline 2057 & 530 & & & & $4,283,300$ & 31 & 226,191 & 7143 & 213.8 & \\
\hline 2058 & 530 & & & & $4,283,300$ & 10 & 74,687 & 2359 & 216.2 & \\
\hline 2059 & 530 & & & & $4,283,300$ & 21 & 155,753 & 4919 & 218.6 & \\
\hline 2060 & 530 & & & & $4,283,300$ & 21 & 157,463 & 4973 & 221.0 & \\
\hline
\end{tabular}

Note: (1) All of the above future values are converted into present ones by applying GDP deflators and discount rates of each year, (2) The future costs of service are estimated by a simple regression analysis based on data from 1995 through 2013, (3) Exchange rate: 1US\$ = 1100 Korean Won.Source: (1) Ministry of Land, Infrastructure and Transport [8], (2) National Information Center (www.gims.go.kr).

Table A2. Cost detail of the SGMN (unit: USD).

\begin{tabular}{|c|c|c|c|c|c|c|c|c|c|c|}
\hline \multirow[b]{2}{*}{ Year } & \multicolumn{2}{|c|}{ SGMN } & \multicolumn{3}{|c|}{ Construction \& Installation } & \multicolumn{2}{|c|}{ Service } & \multirow[b]{2}{*}{ Replacement } & \multirow[b]{2}{*}{ GDP } & \multirow{2}{*}{$\begin{array}{c}\text { Discount } \\
\text { Rate }\end{array}$} \\
\hline & $\begin{array}{c}\text { Nation } \\
\text { Total }\end{array}$ & Plan & Manual & Automatic & RTU & Manual & Automatic & & & \\
\hline 2011 & 1067 & 0 & - & - & - & 513,752 & 871,631 & 2283 & 101.8 & \\
\hline 2012 & 3079 & 447 & 31,941 & $6,613,380$ & 45,326 & 756,016 & $1,282,655$ & 2368 & 105.6 & \\
\hline 2013 & 5092 & 447 & 32,667 & $6,763,684$ & 46,356 & $1,001,354$ & $1,698,896$ & 2422 & 108.0 & \\
\hline 2014 & 7106 & 447 & 33,393 & $6,913,989$ & 47,386 & $1,256,833$ & $2,132,340$ & 2476 & 110.4 & \\
\hline 2015 & 9121 & 447 & 34,119 & $7,064,293$ & 48,416 & $1,522,452$ & $2,582,989$ & 2529 & 112.8 & \\
\hline 2016 & 11137 & 447 & 34,845 & $7,214,597$ & 49,446 & $1,798,211$ & $3,050,842$ & 2583 & 115.2 & \\
\hline 2017 & 13154 & 447 & 35,571 & $7,364,901$ & 50,476 & $2,084,111$ & $3,535,899$ & 2637 & 117.6 & \\
\hline 2018 & 15172 & 447 & 36,297 & $7,515,205$ & 51,506 & $2,380,151$ & $4,038,160$ & 2691 & 120.0 & \\
\hline 2019 & 17191 & 447 & 37,023 & $7,665,509$ & 52,537 & $2,686,331$ & $4,557,624$ & 2745 & 122.4 & \\
\hline 2020 & 19211 & 447 & 37,749 & $7,815,813$ & 53,567 & $3,002,651$ & $5,094,293$ & 2799 & 124.8 & \\
\hline 2021 & 21232 & 447 & 38,475 & $7,966,117$ & 54,597 & $3,329,112$ & $5,648,166$ & 2852 & 127.2 & \\
\hline 2022 & 23254 & 447 & 39,201 & $8,116,421$ & 55,627 & $3,665,713$ & $6,219,242$ & 2906 & 129.6 & \\
\hline 2023 & 25277 & 447 & 39,927 & $8,266,725$ & 56,657 & $4,012,454$ & $6,807,523$ & 2960 & 132.0 & \\
\hline 2024 & 27301 & 447 & 40,653 & $8,417,029$ & 57,687 & $4,369,336$ & $7,413,008$ & 3014 & 134.4 & \\
\hline 2025 & 29326 & 447 & 41,379 & $8,567,334$ & 58,717 & $4,736,358$ & $8,035,696$ & 3068 & 136.8 & $6.5 \%$ \\
\hline 2026 & 31352 & 447 & 42,104 & $8,717,638$ & 59,748 & $5,113,520$ & $8,675,589$ & 3121 & 139.2 & \\
\hline 2027 & 33379 & 447 & 42,830 & $8,867,942$ & 60,778 & $5,500,822$ & $9,332,685$ & 3175 & 141.6 & \\
\hline 2028 & 35407 & 447 & 43,556 & $9,018,246$ & 61,808 & $5,898,265$ & $10,006,986$ & 3229 & 144.0 & \\
\hline 2029 & 37436 & 447 & 44,282 & $9,168,550$ & 62,838 & $6,305,848$ & $10,698,491$ & 3283 & 146.4 & \\
\hline 2030 & 39466 & 447 & 45,008 & $9,318,854$ & 63,868 & 6723571 & $1,1407,199$ & 3337 & 148.8 & \\
\hline 2031 & 41497 & 447 & 45,734 & $9,469,158$ & 64,898 & $7,151,435$ & $12,133,112$ & 3391 & 151.2 & \\
\hline 2032 & & & & & & $7,269,679$ & $12,333,725$ & 3447 & 153.7 & \\
\hline 2033 & & & & & & $7,383,194$ & $12,526,314$ & 3500 & 156.1 & \\
\hline 2034 & & & & & & $7,496,709$ & $12,718,903$ & 3554 & 158.5 & \\
\hline 2035 & & & & & & $7,610,224$ & $12,911,493$ & 3608 & 160.9 & \\
\hline 2036 & & & & & & $7,723,739$ & $13,104,082$ & 3662 & 163.3 & \\
\hline 2037 & & & & & & $7,837,254$ & $13,296,671$ & 3716 & 165.7 & \\
\hline 2038 & & & & & & $7,950,768$ & $13,489,260$ & 3770 & 168.1 & \\
\hline 2039 & & & & & & $8,064,283$ & $13,681,849$ & 3823 & 170.5 & \\
\hline 2040 & & & & & & $8,177,798$ & $13,874,438$ & 3877 & 172.9 & \\
\hline
\end{tabular}


Table A2. Cont.

\begin{tabular}{|c|c|c|c|c|c|c|c|c|c|c|}
\hline \multirow[b]{2}{*}{ Year } & \multicolumn{2}{|c|}{ SGMN } & \multicolumn{3}{|c|}{ Construction \& Installation } & \multicolumn{2}{|c|}{ Service } & \multirow[b]{2}{*}{ Replacement } & \multirow[b]{2}{*}{ GDP } & \multirow[b]{2}{*}{$\begin{array}{l}\text { Discount } \\
\text { Rate }\end{array}$} \\
\hline & $\begin{array}{c}\text { Nation } \\
\text { Total }\end{array}$ & Plan & Manual & Automatic & RTU & Manual & Automatic & & & \\
\hline 2041 & & & & & & $8,291,313$ & $14,067,027$ & 3931 & 175.3 & \\
\hline 2042 & & & & & & $8,404,828$ & $14,259,616$ & 3985 & 177.7 & \\
\hline 2043 & & & & & & $8,518,343$ & $14,452,205$ & 4039 & 180.1 & \\
\hline 2044 & & & & & & $8,631,857$ & $14,644,794$ & 4092 & 182.5 & \\
\hline 2045 & & & & & & $8,745,372$ & $14,837,383$ & 4146 & 184.9 & \\
\hline 2046 & & & & & & $8,858,887$ & $15,029,972$ & 4200 & 187.3 & \\
\hline 2047 & & & & & & $8,972,402$ & $15,222,561$ & 4254 & 189.7 & \\
\hline 2048 & & & & & & $9,085,917$ & $15,415,150$ & 4308 & 192.1 & \\
\hline 2049 & & & & & & $9,199,432$ & $15,607,740$ & 4362 & 194.5 & \\
\hline 2050 & & & & & & $9,312,946$ & $15,800,329$ & 4415 & 196.9 & $5.0 \%$ \\
\hline 2051 & & & & & & $9,426,461$ & $15,992,918$ & 4469 & 199.3 & $5.0 \%$ \\
\hline 2052 & & & & & & $9,539,976$ & $16,185,507$ & 4523 & 201.7 & \\
\hline 2053 & & & & & & $9,658,221$ & $16,386,120$ & 4579 & 204.2 & \\
\hline 2054 & & & & & & $9,771,736$ & $16,578,709$ & 4633 & 206.6 & \\
\hline 2055 & & & & & & $9,885,250$ & $16,771,299$ & 4687 & 209.0 & \\
\hline 2056 & & & & & & $9,998,765$ & $16,963,888$ & 4740 & 211.4 & \\
\hline 2057 & & & & & & $10,112,280$ & $17,156,477$ & 4794 & 213.8 & \\
\hline 2058 & & & & & & $10,225,795$ & $17,349,066$ & 4848 & 216.2 & \\
\hline 2059 & & & & & & $10,339,310$ & $17,541,655$ & 4902 & 218.6 & \\
\hline 2060 & & & & & & $10,452,825$ & $17,734,244$ & 4956 & 221.0 & \\
\hline
\end{tabular}

Notes: (1) All of the above future values are converted into present ones by applying GDP deflators and discount rates of each year, (2) The future costs of service are estimated by a simple regression analysis based on data from 1995 through 2013, (3) Exchange rate: 1US\$=1100 Korean Won.Source: Ministry of Land, Infrastructure and Transport [8]. Source: (1) Ministry of Land, Infrastructure and Transport [8], (2) National Information Center (www.gims.go.kr).

Table A3. Cost detail of the GMFA (unit: USD).

\begin{tabular}{|c|c|c|c|c|c|c|c|c|c|}
\hline \multirow{2}{*}{ Year } & \multirow{2}{*}{ GMFA } & \multicolumn{2}{|c|}{ Construction } & \multirow{2}{*}{ Installation } & \multirow{2}{*}{ Service } & \multicolumn{2}{|c|}{ Replacement } & \multirow{2}{*}{$\begin{array}{c}\text { GDP } \\
\text { Deflator }\end{array}$} & \multirow{2}{*}{$\begin{array}{l}\text { Discount } \\
\text { Rate }\end{array}$} \\
\hline & & Plan & Cost & & & Device & Battery & & \\
\hline 2011 & 84 & 13 & 520,392 & 9,967 & 387,474 & 59,784 & 1888 & 101.8 & \\
\hline 2012 & 107 & 23 & 955,061 & 10,339 & 485,809 & 83,904 & 2650 & 105.6 & \\
\hline 2013 & 212 & 105 & $4,469,768$ & 10,574 & $1,219,556$ & 418,795 & 13,225 & 108 & \\
\hline 2014 & 318 & 105 & $4,569,096$ & 10,809 & $1,927,294$ & 450,984 & 14,242 & 110.4 & \\
\hline 2015 & 423 & 105 & $4,668,425$ & 11,044 & $2,703,688$ & 452,995 & 14,305 & 112.8 & \\
\hline 2016 & 528 & 105 & $4,767,753$ & 11,279 & $3,548,998$ & 458,653 & 14,484 & 115.2 & \\
\hline 2017 & 633 & 105 & $4,867,081$ & 11,514 & $4,463,469$ & 480,396 & 15,170 & 117.6 & \\
\hline 2018 & 739 & 105 & $4,966,409$ & 11,749 & $5,447,333$ & 490,200 & 15,480 & 120.0 & \\
\hline 2019 & 844 & 105 & $5,065,737$ & 11,984 & $6,539,296$ & 516,917 & 16,324 & 122.4 & \\
\hline 2020 & 949 & 105 & $5,165,066$ & 12,219 & $7,669,532$ & 552,921 & 17,461 & 124.8 & \\
\hline 2021 & 1056 & 107 & $5,351,925$ & 12,454 & $8,534,273$ & 963,424 & 30,424 & 127.2 & \\
\hline 2022 & 1056 & & & & $8,534,273$ & 529,416 & 16,718 & 129.6 & \\
\hline 2023 & 1056 & & & & $8,534,273$ & 530,100 & 16,740 & 132.0 & \\
\hline 2024 & 1056 & & & & $8,534,273$ & 535,095 & 16,898 & 134.4 & \\
\hline 2025 & 1056 & & & & $8,534,273$ & 558,828 & 17,647 & 136.8 & $6.5 \%$ \\
\hline 2026 & 1056 & & & & $8,534,273$ & 568,632 & 17,957 & 139.2 & \\
\hline 2027 & 1056 & & & & $8,534,273$ & 598,003 & 18,884 & 141.6 & \\
\hline 2028 & 1056 & & & & $8,534,273$ & 637,985 & 20,147 & 144.0 & \\
\hline 2029 & 1056 & & & & $8,534,273$ & $1,108,847$ & 35,016 & 146.4 & \\
\hline 2030 & 1056 & & & & $8,534,273$ & 607,848 & 19,195 & 148.8 & \\
\hline 2031 & 1056 & & & & $8,534,273$ & 607,205 & 19,175 & 151.2 & \\
\hline 2032 & 1056 & & & & $8,534,273$ & 611,936 & 19,324 & 153.7 & \\
\hline 2033 & 1056 & & & & $8,534,273$ & 637,669 & 20,137 & 156.1 & \\
\hline 2034 & 1056 & & & & $8,534,273$ & 647,473 & 20,447 & 158.5 & \\
\hline 2035 & 1056 & & & & $8,534,273$ & 679,510 & 21,458 & 160.9 & \\
\hline 2036 & 1056 & & & & $8,534,273$ & 723,493 & 22,847 & 163.3 & \\
\hline 2037 & 1056 & & & & $8,534,273$ & $1,255,027$ & 39,632 & 165.7 & \\
\hline 2038 & 1056 & & & & $8,534,273$ & 686,689 & 21,685 & 168.1 & \\
\hline 2039 & 1056 & & & & $8,534,273$ & 684,713 & 21,623 & 170.5 & \\
\hline 2040 & 1056 & & & & $8,534,273$ & 688,378 & 21,738 & 172.9 & \\
\hline
\end{tabular}


Table A3. Cont.

\begin{tabular}{|c|c|c|c|c|c|c|c|c|c|}
\hline \multirow{2}{*}{ Year } & \multirow{2}{*}{ GMFA } & \multicolumn{2}{|c|}{ Construction } & \multirow{2}{*}{ Installation } & \multirow{2}{*}{ Service } & \multicolumn{2}{|c|}{ Replacement } & \multirow{2}{*}{$\begin{array}{c}\text { GDP } \\
\text { Deflator }\end{array}$} & \multirow{2}{*}{$\begin{array}{c}\text { Discount } \\
\text { Rate }\end{array}$} \\
\hline & & Plan & Cost & & & Device & Battery & & \\
\hline 2041 & 1056 & & & & $8,534,273$ & 716,101 & 22,614 & 175.3 & \\
\hline 2042 & 1056 & & & & $8,534,273$ & 725,905 & 22,923 & 177.7 & \\
\hline 2043 & 1056 & & & & $8,534,273$ & 760,595 & 24,019 & 180.1 & \\
\hline 2044 & 1056 & & & & $8,534,273$ & 808,558 & 25,533 & 182.5 & \\
\hline 2045 & 1056 & & & & $8,534,273$ & $1,400,449$ & 44,225 & 184.9 & \\
\hline 2046 & 1056 & & & & $8,534,273$ & 765,121 & 24,162 & 187.3 & \\
\hline 2047 & 1056 & & & & $8,534,273$ & 761,818 & 24,057 & 189.7 & \\
\hline 2048 & 1056 & & & & $8,534,273$ & 764,820 & 24,152 & 192.1 & \\
\hline 2049 & 1056 & & & & $8,534,273$ & 794,533 & 25,091 & 194.5 & \\
\hline 2050 & 1056 & & & & $8,534,273$ & 790,733 & 24,971 & 196.9 & $50 \%$ \\
\hline 2051 & 1056 & & & & $8,534,273$ & 814,141 & 25,710 & 199.3 & \\
\hline 2052 & 1056 & & & & $8,534,273$ & 893,623 & 28,220 & 201.7 & \\
\hline 2053 & 1056 & & & & $8,534,273$ & $1,497,250$ & 47,282 & 204.2 & \\
\hline 2054 & 1056 & & & & $8,534,273$ & 751,179 & 23,721 & 206.6 & \\
\hline 2055 & 1056 & & & & $8,534,273$ & 759,905 & 23,997 & 209.0 & \\
\hline 2056 & 1056 & & & & $8,534,273$ & 768,631 & 24,273 & 211.4 & \\
\hline 2057 & 1056 & & & & $8,534,273$ & 777,357 & 24,548 & 213.8 & \\
\hline 2058 & 1056 & & & & $8,534,273$ & 786,084 & 24,824 & 216.2 & \\
\hline 2059 & 1056 & & & & $8,534,273$ & 794,810 & 25,099 & 218.6 & \\
\hline 2060 & 1056 & & & & $8,534,273$ & 803,536 & 25,375 & 221.0 & \\
\hline
\end{tabular}

Note: (1) All of the above future values are converted into present ones by applying GDP deflators and discount rates of each year, (2) The future costs of service are estimated by a simple regression analysis based on data from 1995 through 2013, (3) Exchange rate: 1US\$=1100 Korean Won, *). Source: (1) Ministry of Land, Infrastructure and Transport [8], (2) National Information Center (www.gims.go.kr).

Table A4. Cost detail of the SIMN (unit: USD).

\begin{tabular}{|c|c|c|c|c|c|c|c|c|c|}
\hline \multirow{2}{*}{ Year } & \multirow{2}{*}{ SIMN } & \multicolumn{2}{|c|}{ Construction } & \multirow{2}{*}{ Installation } & \multirow{2}{*}{ Service } & \multicolumn{2}{|c|}{ Replacement } & \multirow{2}{*}{$\begin{array}{c}\text { GDP } \\
\text { Deflator }\end{array}$} & \multirow{2}{*}{$\begin{array}{l}\text { Discount } \\
\text { Rate }\end{array}$} \\
\hline & & Plan & Cost & & & Device & Battery & & \\
\hline 2011 & 117 & 8 & 336,253 & 83,724 & 78,890 & 58,114 & 1835 & 101.8 & \\
\hline 2012 & 127 & 10 & 415,244 & 103,392 & 608,905 & 66,120 & 2088 & 105.6 & \\
\hline 2013 & 136 & 9 & 382,213 & 95,168 & 843,950 & 63,892 & 2018 & 108.0 & \\
\hline 2014 & 168 & 32 & $1,367,473$ & 340,489 & $1,122,504$ & 151,123 & 4772 & 110.4 & \\
\hline 2015 & 199 & 32 & $1,397,201$ & 347,891 & $1,435,606$ & 161,714 & 5107 & 112.8 & \\
\hline 2016 & 231 & 32 & $1,426,928$ & 355,293 & $1,784,823$ & 191,122 & 6035 & 115.2 & \\
\hline 2017 & 262 & 32 & $1,456,656$ & 362,694 & $2,171,731$ & 195,104 & 6161 & 117.6 & \\
\hline 2018 & 294 & 32 & $1,486,384$ & 370,096 & $2,597,902$ & 199,085 & 6287 & 120.0 & \\
\hline 2019 & 325 & 32 & $1,516,111$ & 377,498 & $3,083,060$ & 203,067 & 6413 & 122.4 & \\
\hline 2020 & 357 & 32 & $1,545,839$ & 384,900 & $3,595,645$ & 207,049 & 6538 & 124.8 & \\
\hline 2021 & 388 & 32 & $1,575,567$ & 392,302 & $3,988,609$ & 218,061 & 6886 & 127.2 & \\
\hline 2022 & 388 & & & & $4,063,866$ & 76,670 & 2421 & 129.6 & \\
\hline 2023 & 388 & & & & $4,139,123$ & 180,690 & 5706 & 132.0 & \\
\hline 2024 & 388 & & & & $4,214,379$ & 192,681 & 6085 & 134.4 & \\
\hline 2025 & 388 & & & & $4,289,636$ & 226,957 & 7167 & 136.8 & $6.5 \%$ \\
\hline 2026 & 388 & & & & $4,364,893$ & 230,939 & 7293 & 139.2 & \\
\hline 2027 & 388 & & & & $4,440,150$ & 234,921 & 7419 & 141.6 & \\
\hline 2028 & 388 & & & & $4,515,406$ & 238,903 & 7544 & 144.0 & \\
\hline 2029 & 388 & & & & $4,590,663$ & 242,884 & 7670 & 146.4 & \\
\hline 2030 & 388 & & & & $4,665,920$ & 255,091 & 8055 & 148.8 & \\
\hline 2031 & 388 & & & & $4,741,177$ & 89,449 & 2825 & 151.2 & \\
\hline 2032 & 388 & & & & $4,819,569$ & 210,394 & 6644 & 153.7 & \\
\hline 2033 & 388 & & & & $4,894,826$ & 223,791 & 7067 & 156.1 & \\
\hline 2034 & 388 & & & & $4,970,083$ & 262,959 & 8304 & 158.5 & \\
\hline 2035 & 388 & & & & $5,045,340$ & 266,940 & 8430 & 160.9 & \\
\hline 2036 & 388 & & & & $5,120,596$ & 270,922 & 8555 & 163.3 & \\
\hline 2037 & 388 & & & & $5,195,853$ & 274,904 & 8681 & 165.7 & \\
\hline 2038 & 388 & & & & $5,271,110$ & 278,886 & 8807 & 168.1 & \\
\hline 2039 & 388 & & & & $5,346,367$ & 292,291 & 9230 & 170.5 & \\
\hline 2040 & 388 & & & & $5,421,623$ & 102,286 & 3230 & 172.9 & \\
\hline
\end{tabular}


Table A4. Cont.

\begin{tabular}{|c|c|c|c|c|c|c|c|c|c|}
\hline \multirow{2}{*}{ Year } & \multirow{2}{*}{ SIMN } & \multicolumn{2}{|c|}{ Construction } & \multirow{2}{*}{ Installation } & \multirow{2}{*}{ Service } & \multicolumn{2}{|c|}{ Replacement } & \multirow{2}{*}{$\begin{array}{c}\text { GDP } \\
\text { Deflator }\end{array}$} & \multirow{2}{*}{$\begin{array}{c}\text { Discount } \\
\text { Rate }\end{array}$} \\
\hline & & Plan & Cost & & & Device & Battery & & \\
\hline 2041 & 388 & & & & $5,496,880$ & 239,962 & 7578 & 175.3 & \\
\hline 2042 & 388 & & & & $5,572,137$ & 254,757 & 8045 & 177.7 & \\
\hline 2043 & 388 & & & & $5,647,394$ & 298,794 & 9436 & 180.1 & \\
\hline 2044 & 388 & & & & $5,722,651$ & 302,776 & 9561 & 182.5 & \\
\hline 2045 & 388 & & & & $5,797,907$ & 306,758 & 9687 & 184.9 & \\
\hline 2046 & 388 & & & & $5,873,164$ & 310,739 & 9813 & 187.3 & \\
\hline 2047 & 388 & & & & $5,948,421$ & 314,721 & 9939 & 189.7 & \\
\hline 2048 & 388 & & & & $6,023,678$ & 329,321 & 10400 & 192.1 & \\
\hline 2049 & 388 & & & & $6,098,934$ & 115,064 & 3634 & 194.5 & \\
\hline 2050 & 388 & & & & $6,174,191$ & 269,529 & 8511 & 196.9 & $50 \%$ \\
\hline 2051 & 388 & & & & $6,249,448$ & 285,724 & 9023 & 199.3 & \\
\hline 2052 & 388 & & & & $6,324,705$ & 278,016 & 8779 & 201.7 & \\
\hline 2053 & 388 & & & & $6,403,097$ & 281,462 & 8888 & 204.2 & \\
\hline 2054 & 388 & & & & $6,478,354$ & 284,770 & 8993 & 206.6 & \\
\hline 2055 & 388 & & & & $6,553,611$ & 288,078 & 9097 & 209.0 & \\
\hline 2056 & 388 & & & & $6,628,868$ & 291,386 & 9202 & 211.4 & \\
\hline 2057 & 388 & & & & $6,704,124$ & 306,511 & 9679 & 213.8 & \\
\hline 2058 & 388 & & & & $6,779,381$ & 67,219 & 2123 & 216.2 & \\
\hline 2059 & 388 & & & & $6,854,638$ & 237,877 & 7512 & 218.6 & \\
\hline 2060 & 388 & & & & $6,929,895$ & 240,488 & 7594 & 221.0 & \\
\hline
\end{tabular}

Note: (1) All of the above future values are converted into present ones by applying GDP deflators and discount rates of each year, (2) The future costs of service are estimated by a simple regression analysis based on data from 1995 through 2013, (3) Exchange rate: 1US\$ = 1100 Korean Won, ${ }^{*}$ ). Source: (1) Ministry of Land, Infrastructure and Transport [8], (2) National Information Center (www.gims.go.kr).

Table A5. Cost detail of the GQM (unit: USD).

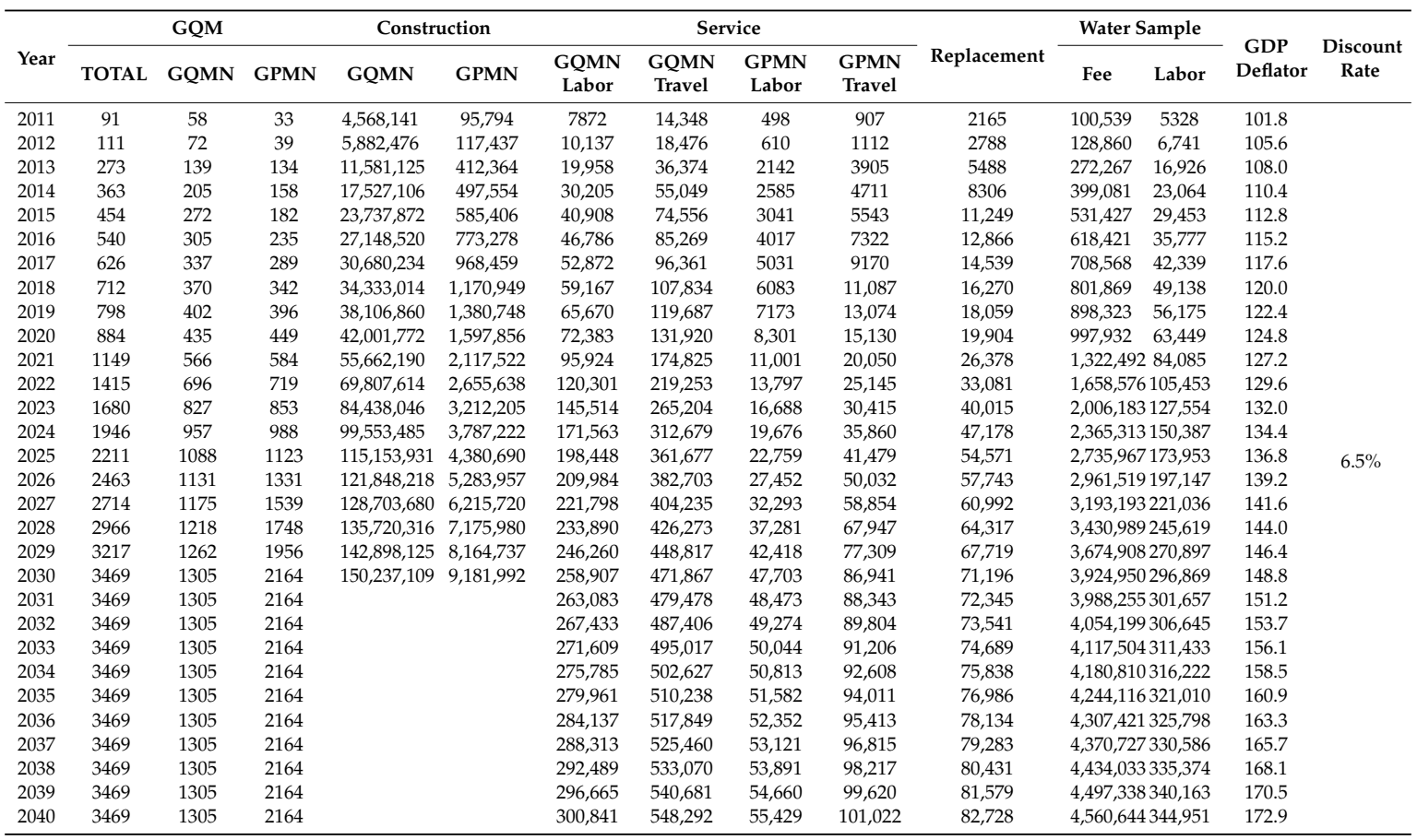


Table A5. Cont.

\begin{tabular}{|c|c|c|c|c|c|c|c|c|c|c|c|c|c|c|}
\hline \multirow[b]{2}{*}{ Year } & \multicolumn{3}{|c|}{ GQM } & \multicolumn{2}{|c|}{ Construction } & \multicolumn{4}{|c|}{ Service } & \multirow[b]{2}{*}{ Replacement } & \multicolumn{2}{|c|}{ Water Sample } & \multirow[b]{2}{*}{$\begin{array}{l}\text { GDP } \\
\text { Deflator }\end{array}$} & \multirow[b]{2}{*}{$\begin{array}{l}\text { Discount } \\
\text { Rate }\end{array}$} \\
\hline & TOTAL & GQMN & GPMN & GQMN & GPMN & $\begin{array}{l}\text { GQMN } \\
\text { Labor }\end{array}$ & $\begin{array}{c}\text { GQMN } \\
\text { Travel }\end{array}$ & $\begin{array}{l}\text { GPMN } \\
\text { Labor }\end{array}$ & $\begin{array}{l}\text { GPMN } \\
\text { Travel }\end{array}$ & & Fee & Labor & & \\
\hline 2041 & 3469 & 1305 & 2164 & & & 305,016 & 555,903 & 56,199 & 102,424 & 83,876 & $4,623,95$ & 0349,739 & 175.3 & \\
\hline 2043 & 3469 & 1305 & 2164 & & & 313,368 & 571,124 & 57,738 & 105,229 & 86,173 & $4,750,56$ & 1359,315 & 180.1 & \\
\hline 2044 & 3469 & 1305 & 2164 & & & 317,544 & 578,735 & 58,507 & 106,631 & 87,321 & $4,813,86$ & 6364,104 & 182.5 & \\
\hline 2045 & 3469 & 1305 & 2164 & & & 321,720 & 586,346 & 59,276 & 108,033 & 88,469 & $4,877,17$ & 2368,892 & 184.9 & \\
\hline 2046 & 3469 & 1305 & 2164 & & & 325,896 & 593,956 & 60,046 & 109,436 & 89,618 & $4,940,47$ & 8373,680 & 187.3 & \\
\hline 2049 & 3469 & 1305 & 2164 & & & 338,424 & 616,789 & 62,354 & 113,642 & 93,063 & $5,130,39$ & 5388,045 & 194.5 & \\
\hline 2050 & 3469 & 1305 & 2164 & & & 342,600 & 624,399 & 63,124 & 115,045 & 94,211 & $5,193,70$ & 0392,833 & 196.9 & $5.0 \%$ \\
\hline 2051 & 3469 & 1305 & 2164 & & & 346,776 & 632,010 & 63,893 & 116,447 & 95,359 & $5,257,00$ & 6397,621 & 199.3 & \\
\hline 2052 & 3469 & 1305 & 2164 & & & 350,952 & 639,621 & 64,662 & 117,849 & 96,508 & $5,320,31$ & 2402,409 & 201.7 & \\
\hline 2053 & 3469 & 1305 & 2164 & & & 355,302 & 647,549 & 65,464 & 119,310 & 97,704 & $5,386,25$ & 5 407,397 & 204.2 & \\
\hline 2054 & 3469 & 1305 & 2164 & & & 359,477 & 655,160 & 66,233 & 120,712 & 98,852 & $5,449,56$ & 1412,185 & 206.6 & \\
\hline 2055 & 3469 & 1305 & 2164 & & & 363,653 & 662,770 & 67,003 & 122,115 & 100,000 & $5,512,86$ & 6416,973 & 209.0 & \\
\hline
\end{tabular}

Notes: (1) All of the above future values are converted into present ones by applying GDP deflators and discount rates of each year, (2) The future costs of service are estimated by a simple regression analysis based on data from 1995 through 2013, (3) Exchange rate: 1US\$ = 1100 Korean Won, ${ }^{*}$ ) Source: Ministry of Land, Infrastructure and Transport [8]. Source: (1) Ministry of Land, Infrastructure and Transport [8], (2) National Information Center (www.gims.go.kr).

Table A6. Cost detail of the LQMN (unit: USD).

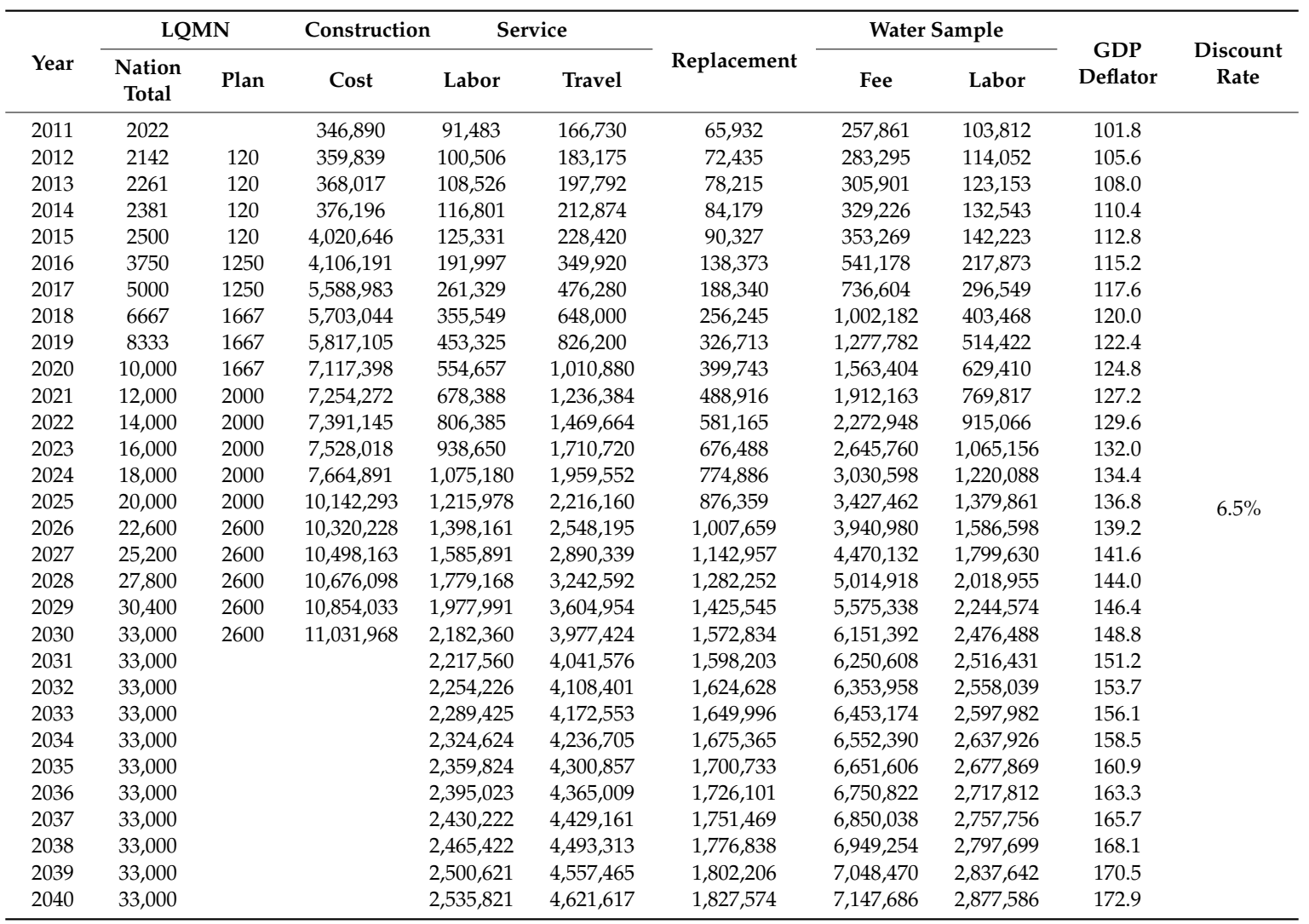


Table A6. Cont.

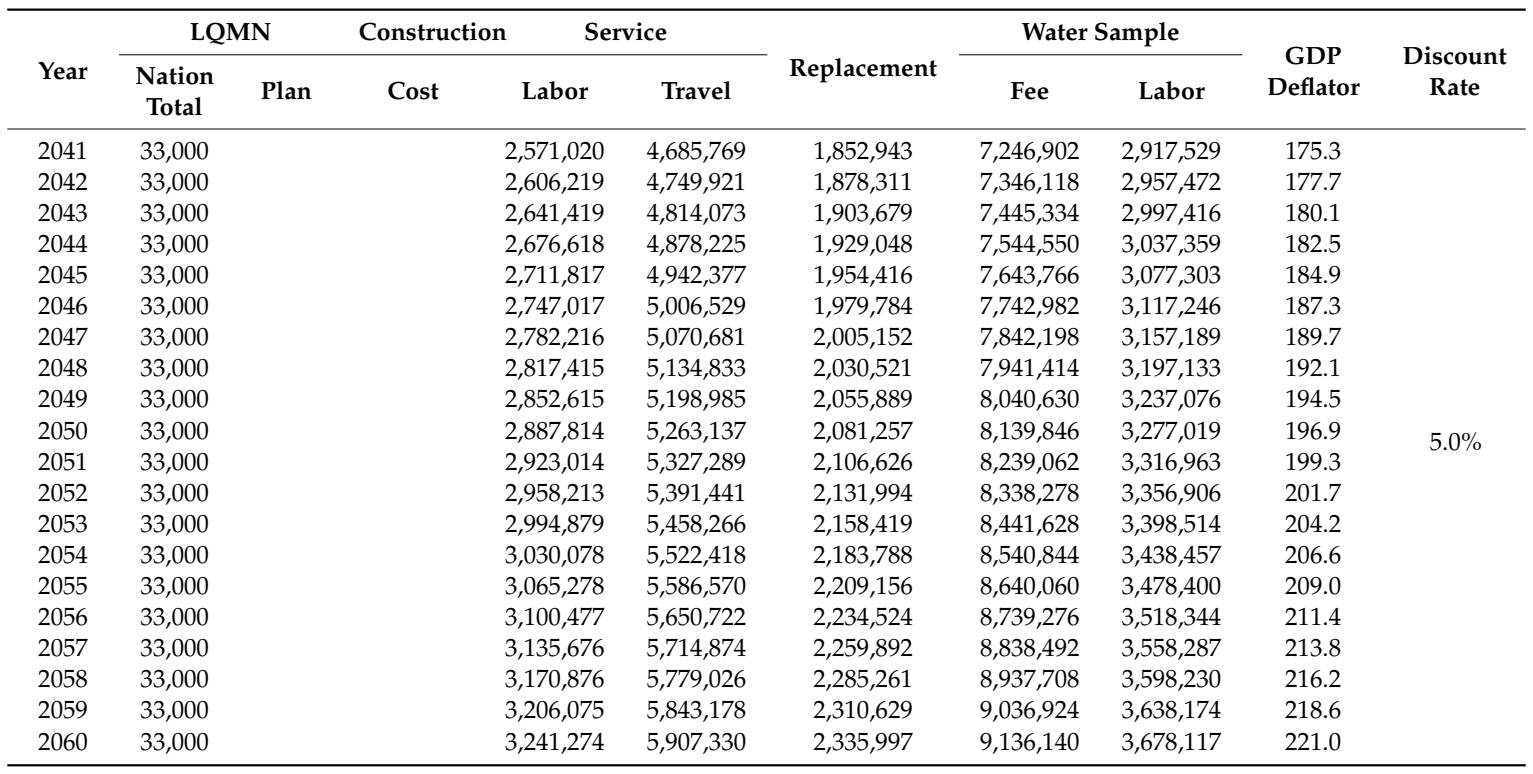

Notes: (1) All of the above future values are converted into present ones by applying GDP deflators and discount rates of each year, (2) The future costs of service are estimated by a simple regression analysis based on data from 1995 through 2013, (3) Exchange rate: 1US\$ = 1100 Korean Won, ${ }^{*}$ ). Source: (1) Ministry of Land, Infrastructure and Transport [8], (2) National Information Center (www.gims.go.kr).

\section{Appendix B}

Table A7. Projection of groundwater monitoring wells by type.

\begin{tabular}{|c|c|c|c|c|c|c|}
\hline Year & NGMN & SGMN & GMFN & QMN & LQMN & SIMN \\
\hline 2010 & 335 & 1067 & 71 & 58 & 2022 & 136 \\
\hline 2011 & 348 & 1067 & 84 & 91 & 2022 & 134 \\
\hline 2012 & 414 & 1008 & 107 & 48 & 2123 & 143 \\
\hline 2013 & 435 & 1069 & 79 & 52 & 2144 & 153 \\
\hline 2014 & 455 & 1131 & 85 & 55 & 2166 & 162 \\
\hline 2015 & 476 & 1193 & 91 & 59 & 2187 & 172 \\
\hline 2016 & 496 & 1255 & 97 & 63 & 2209 & 181 \\
\hline 2017 & 517 & 1317 & 102 & 67 & 2230 & 191 \\
\hline 2018 & 530 & 1379 & 108 & 71 & 2251 & 200 \\
\hline 2019 & 530 & 1441 & 114 & 74 & 2273 & 210 \\
\hline 2020 & 530 & 1503 & 119 & 78 & 2294 & 219 \\
\hline 2021 & 530 & 1564 & 125 & 82 & 2315 & 229 \\
\hline 2022 & 530 & 1626 & 131 & 86 & 2337 & 238 \\
\hline 2023 & 530 & 1688 & 136 & 90 & 2358 & 248 \\
\hline 2024 & 530 & 1750 & 142 & 94 & 2380 & 257 \\
\hline 2025 & 530 & 1812 & 148 & 97 & 2401 & 267 \\
\hline 2026 & 530 & 1874 & 153 & 101 & 2422 & 276 \\
\hline 2027 & 530 & 1936 & 159 & 105 & 2444 & 286 \\
\hline 2028 & 530 & 1997 & 165 & 109 & 2465 & 295 \\
\hline 2029 & 530 & 2059 & 170 & 113 & 2486 & 305 \\
\hline 2030 & 530 & 2121 & 176 & 116 & 2508 & 314 \\
\hline 2031 & 530 & 2183 & 182 & 120 & 2529 & 324 \\
\hline 2032 & 530 & 2245 & 187 & 124 & 2550 & 333 \\
\hline 2033 & 530 & 2307 & 193 & 128 & 2572 & 343 \\
\hline 2034 & 530 & 2369 & 199 & 132 & 2593 & 352 \\
\hline 2035 & 530 & 2431 & 205 & 135 & 2615 & 362 \\
\hline 2036 & 530 & 2492 & 210 & 139 & 2636 & 371 \\
\hline 2037 & 530 & 2554 & 216 & 143 & 2657 & 381 \\
\hline 2038 & 530 & 2616 & 222 & 147 & 2679 & 388 \\
\hline 2039 & 530 & 2678 & 227 & 151 & 2700 & 388 \\
\hline 2040 & 530 & 2740 & 233 & 155 & 2721 & 388 \\
\hline 2041 & 530 & 2802 & 239 & 158 & 2743 & 388 \\
\hline 2042 & 530 & 2864 & 244 & 162 & 2764 & 388 \\
\hline 2043 & 530 & 2925 & 250 & 166 & 2786 & 388 \\
\hline
\end{tabular}


Table A7. Cont.

\begin{tabular}{ccccccc}
\hline Year & NGMN & SGMN & GMFN & QMN & LQMN & SIMN \\
\hline 2044 & 530 & 2987 & 256 & 170 & 2807 & 388 \\
2045 & 530 & 3049 & 261 & 174 & 2828 & 388 \\
2046 & 530 & 3111 & 267 & 177 & 2850 & 388 \\
2047 & 530 & 3173 & 273 & 181 & 2871 & 388 \\
2048 & 530 & 3235 & 278 & 185 & 2892 & 388 \\
2049 & 530 & 3297 & 284 & 189 & 2914 & 388 \\
2050 & 530 & 3359 & 290 & 193 & 2935 & 388 \\
2051 & 530 & 3420 & 295 & 196 & 2957 & 388 \\
2052 & 530 & 3482 & 301 & 200 & 2978 & 388 \\
2053 & 530 & 3544 & 307 & 204 & 2999 & 388 \\
2054 & 530 & 3606 & 313 & 208 & 3021 & 388 \\
2055 & 530 & 3668 & 318 & 212 & 3042 & 388 \\
2056 & 530 & 3730 & 324 & 216 & 3063 & 388 \\
2057 & 530 & 3792 & 330 & 219 & 3085 & 388 \\
2058 & 530 & 3853 & 335 & 223 & 3106 & 388 \\
2059 & 530 & 3915 & 341 & 227 & 3127 & 388 \\
2060 & 530 & 3977 & 347 & 231 & 3149 & 388 \\
\hline
\end{tabular}

Notes: The number of wells is estimated by a simple regression analysis based on data from 1995 through 2013. Source: (1) Ministry of Land, Infrastructure and Transport [8], (2) National Information Center (www.gims.go.kr).

\section{References}

1. United Nations University. Global Water Crisis: The Facts; Institute for Water, Environment and Health: Hamilton, ON, Canada, 2017.

2. World Bank Group. High and Dry: Climate Change, Water, and the Economy; World Bank: Washington, DC, USA, 2016. Available online: http://documents.worldbank.org/curated/en/862571468196731247/High-anddry-climate-change-water-and-the-economy (accessed on 10 February 2019).

3. Khair, S.M.; Mushtaq, S.; Kathryn, R.S. Groundwater Governance in a Water-starved Country: Public Policy, Farmers' Perceptions, and Drivers of Tubewell Adoption in Balochistan, Pakistan. Groundwater 2015, 53, 626-637. [CrossRef] [PubMed]

4. Environment Agency. Using Science to Create a Better Place: Assessing the Value of Groundwater; Science Report-SC040016/SR1; Environment Agency: Bristol, UK, 2007.

5. Livingston, M.L.; Garrido, A. Entering the Policy Debate: An Economic Evaluation of Groundwater Policy in Flux. Water Resour. Res. 2004, 40. [CrossRef]

6. Ma, F.; Gao, H.; Eneji, A.E.; Jin, Z.; Han, L.; Liu, J. An Economic Valuation of Groundwater Management for Agriculture in Luancheng County, North China. Agric. Water Manag. 2016, 163, 28-36. [CrossRef]

7. Ward, F.A. Cost-benefit and Water Resources Policy: A Survey. Water Policy 2012, 14, 250. [CrossRef]

8. Ministry of Land, Infrastructure and Transport (MLIT). Basic Plan for National Groundwater Management (2012-2021); MLIT: Seoul, Korea, 2012. Available online: http://cleangwater.cafe24.com/gwatersystem.pdf (accessed on 10 February 2019).

9. Lee, J.Y.; Kwon, K.D. Current Status of Groundwater Monitoring Networks in Korea. Water 2016, 8, 168. [CrossRef]

10. Lee, J.Y.; Yi, M.J.; Yoo, Y.K.; Ahn, K.H.; Kim, G.B.; Won, J.H. A Review of the National Groundwater Monitoring Network in Korea. Hydrol. Process. 2007, 21, 907. [CrossRef]

11. Ministry of Land, Transport and Maritime Affairs (MLTM). Basic Plan for National Groundwater Management, 1st ed.; MLTM: Seoul, Korea, 1996. Available online: http://www.riss.kr/search/detail/DetailView.do?p_mat_ type $=695$ c7ada7e580906\&control_no=a450fd6bc18614a4\#redirect (accessed on 9 March 2019).

12. Ellison, R.A.; Calow, R.C. The Economic Value of BGS Geological Mapping in the UK; British Geological Survey: Nottingham, UK, 1996.

13. Reedman, A.J.; Calow, R.; Johnson, C.C.; Piper, D.P.; Bate, D.G. The Value of Geoscience Information in Less Developed Countries; Research Report CR/02/087N; British Geological Survey: Nottingham, UK, 2002.

14. Bernknopf, R.L.; Brookshire, D.S.; McKee, M.J.; Soller, D.R.; Sutter, J.F.; Matti, J.C.; Campbell, R.H. Societal Value of Geologic Maps; U.S. Geological Survey Circular 1111; U.S. Geological Survey: Reston, VA, USA, 1996; pp. 19-41. 
15. Bernknopf, R.L.; Brookshire, D.S.; McKee, M.J.; Soller, D.R. Estimating the Social Value of Geologic Map Information: A Regulatory Application. J. Environ. Econ. Manag. 1996, 32, 204-218. [CrossRef]

16. Halsing, D.; Theissen, K.; Bernknopf, R.L. A Cost-Benefit Analysis of the National Map; U.S. Geological Survey Circular No. 1271; U.S. Department of the Interior: Washington, DC, USA, 2004.

17. Kim, D.H.; Lee, K.H.; Kim, J.W.; Ahn, E.Y. Cost/benefit Analysis of Korean Geological Maps Applying the BGS Method. J. Korean Inst. Miner. Energy Resour. Eng. 2006, 43, 13.

18. Hamilton, B.A. Geospatial Interoperability Return on Investment Study; National Aeronautics and Space Administration Geospatial Interoperability Office: Greenbelt, MD, USA, 2005.

19. Tsangaratos, P.; Koumantakis, I. The Value of Geological Data, Information and Knowledge in Producing Landslide Susceptibility Maps. Bull. Geol. Soc. Greece XLVII 2013, 3, 1529. [CrossRef]

20. Bhagwat, S.B.; Berg, R.C. Benefits and Costs of Geologic Mapping Programs in Illinois: Case Study of Boone and Winnebago Counties and Its Statewide Applicability; Circular No. 549; Illinois State Geological Survey: Champaign, IL, USA, 1991.

21. Boyle, K.J.; Bergstrom, J.C.; Job, C.; Kealy, M.J.; Bergman, R.; Ankrah, R.; Ali, G.; Alsadek, J.; Ballard, G.; Daub, V.; et al. A Framework for Measuring the Economic Benefits of Ground Water; Paper Number EE-0259; United States Environmental Protection Agency: Washington, DC, USA, 1995.

22. Bhagwat, S.B.; Ipe, V.C. Economic Benefits of Detailed Geologic Mapping to Kentucky; Special Report No. 3; Illinois State Geological Survey: Champaign, IL, USA, 2000.

23. Bouma, J.A.; van der Woerd, H.J.; Kuik, O.J. Assessing the Value of Information for Water Quality Management in the North Sea. J. Environ. Manag. 2009, 90, 1280-1288. [CrossRef] [PubMed]

24. Castelein, W.T.; Bregt, A.K.; Pluijmers, Y. The Economic Value of the Dutch Geo-information Sector. Int. J. Spat. Data Infrastruct. Res. 2010, 5, 58.

25. Martinez-Paz, P.A. Environmental Cost of Groundwater: A Contingent Valuation Approach. Int. J. Environ. Res. 2011, 45, 3. [CrossRef]

26. Korea Development Institute (KDI). National Standard Guideline of a Feasibility Study of Water Resources Project; KDI: Seoul, Korea, 2008. Available online: http://webcache.googleusercontent.com/search?q= cache:fSKf0nSVF2QJ:pimac.kdi.re.kr/guide/rguide_list.jsp+\&cd=1\&hl=ko\&ct=clnk\&gl=kr (accessed on 10 February 2019).

27. Kallas, Z.; Gomez-Limon, J.A.; Hurle, J.B. Decomposing the Value of Agricultural Multifunctionality: Combining Contingent Valuation and the Analytical Hierarchy Process. J. Agric. Econ. 2007, 58, 218-241. [CrossRef]

28. Martinez-Paz, J.; Almansa, C.; Casasnovas, V.; Colino, J. Pooling Expert Opinion on Environmental Discounting: An International Delphi Survey. Conserv. Soc. 2016, 14, 243-253. [CrossRef]

29. Kim, G.B.; Ahn, J.S.; Marui, A. Analytic Hierarchy Models for Regional Groundwater Monitoring Well Allocation in Southeast Asian Countries and South Korea. Environ. Earth Sci. 2009, 59, 325. [CrossRef]

30. Saaty, T.L. The Analytic Hierarchy Process; Mcgraw-Hill: New York, NY, USA, 1980.

31. Saaty, T.L. How to Make a Decision: The Analytic Hierarchy Process. Eur. J. Oper. Res. 1990, 48, 9-26. [CrossRef]

32. Saaty, T.L. Decision Making for Readers: The Analytic Hierarchy Process for Decisions in a Complex World, 3rd ed.; RWS Publications: Pittsburgh, PA, USA, 1999.

33. Saaty, T.L. Relative Measurement and Its Generalization in Decision Making Why Pairwise Comparisons are Central Mathematics for the Measurement of Intangible Factors the Analytic Hierarchy/Network Process. Rev. R. Acad. Cienc. Ser. A Mater. 2008, 102, 251-318. [CrossRef]

34. Marcouiller, D.; Coggins, S. The Economic Value of Water: An Introduction; University of Wisconsin-Extension Publication G-3698-1; University of Wisconsin-Extension: Madison, WI, USA, 1999.

35. Ryoo, S.B. On the Etymology and Definition of Changma. Atmosphere 2001, 11, 6-12.

36. Bates, B.; Kundzewicz, Z.W.; Wu, S.; Palutikof, J. (Eds.) Climate Change and Water, Intergovernmental Panel on Climate Change; IPCC Technical Paper; IPCC: Geneva, Switzerland, 2008. Available online: http://www.taccire. suanet.ac.tz:8080/xmlui/bitstream/handle/123456789/552/climate-change-water-en.pdf?sequence=1 (accessed on 17 March 2019).

(C) 2019 by the authors. Licensee MDPI, Basel, Switzerland. This article is an open access article distributed under the terms and conditions of the Creative Commons Attribution (CC BY) license (http://creativecommons.org/licenses/by/4.0/). 